\title{
Domestic Investment and the Cost of Capital in the Caribbean
}

Shaun K. Roache 



\title{
IMF Working Paper
}

Western Hemisphere Department

\section{Domestic Investment and the Cost of Capital in the Caribbean}

\author{
Prepared by Shaun K. Roache ${ }^{1}$ \\ Authorized for distribution by David O. Robinson
}

June 2006

\begin{abstract}
This Working Paper should not be reported as representing the views of the IMF. The views expressed in this Working Paper are those of the author(s) and do not necessarily represent those of the IMF or IMF policy. Working Papers describe research in progress by the author(s) and are published to elicit comments and to further debate.

Investment-to-GDP ratios across the Caribbean tend to be relatively high. In many countries, these ratios have been trending higher since the mid-1990s, largely reflecting public investment and foreign direct investment. Private domestic investors have been less prominent. This may be one reason why such high investment has delivered Caribbean growth rates below the middle-income average. This paper seeks to understand how higher private investment may be encouraged. Using new data, it concludes that: the multiplier effects of public investment and FDI on private domestic investment are weak; and private domestic investment (PDI) is sensitive to the cost of capital. Public policy designed to raise PDI should focus on creating conditions for a lower cost of capital. The focus should be on removing barriers to lower real interest rates, rather than the further extension of costly tax concessions.
\end{abstract}

JEL Classification Numbers: E22, H25, H32, O16

Keywords: Investment, cost of capital

Author(s) E-Mail Address: sroache@imf.org

\footnotetext{
${ }^{1}$ I am grateful to David O. Robinson, Paul Cashin, Jinqing Chai, Rupa Duttagupta, Judith Gold, Rishi Goyal, Hans Peter Lankes, Sanjaya Panth, Tobias Rasmussen, Yan Sun, Chris Towe, Nancy Wagner, colleagues in the Caribbean I Division, and seminar participants in the Western Hemisphere Department and at the Dominica Ministry of Finance for valuable comments and suggestions.
} 


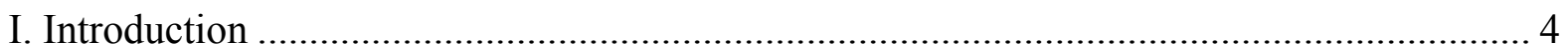

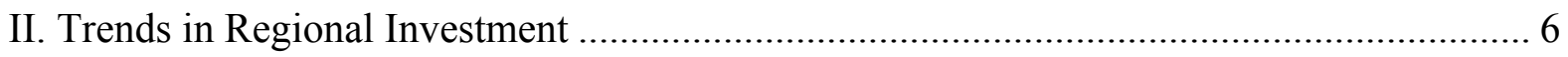

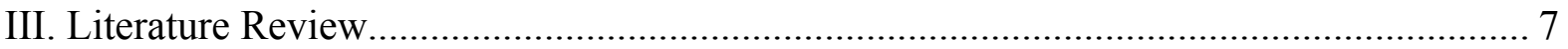

A. Neoclassical Aggregate Capital Stock Models ......................................................... 7

B. Empirical Applications to Middle-Income Economies ........................................... 9

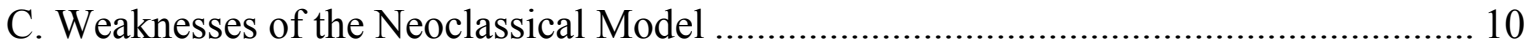

IV. A Basic Investment Model .................................................................................. 11

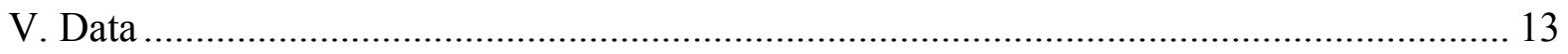

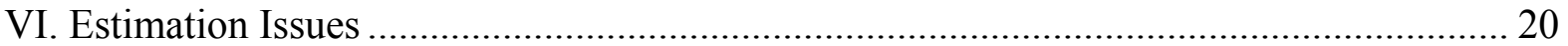

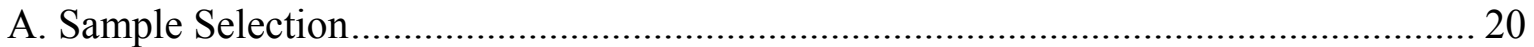

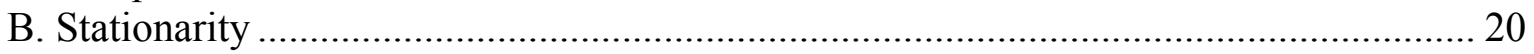

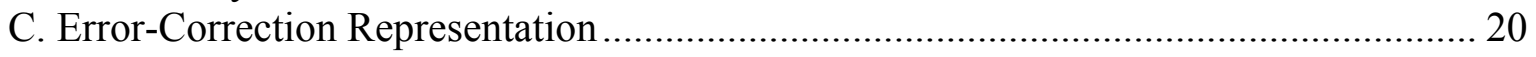

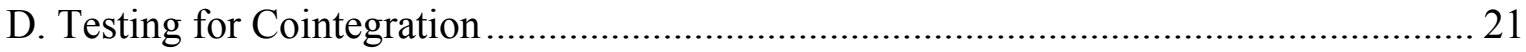

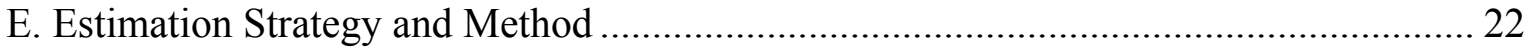

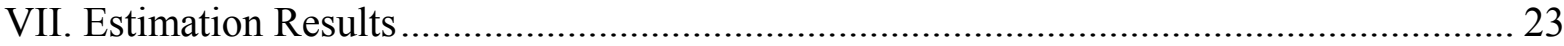

A. Cost of Capital Matters for Domestic Investment .................................................... 23

B. Limited Effects of Output, Public Investment, and FDI ........................................... 24

C. Limited Effect of the External Public Debt-to-GDP Ratio ......................................... 24

D. Little Evidence of Credit Rationing ................................................................... 24

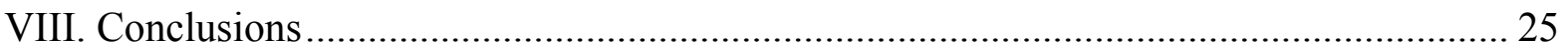

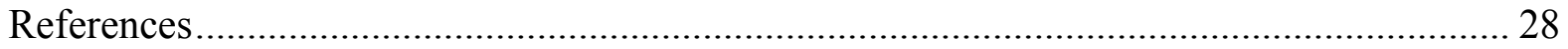

Tables

1. Gross Investment across CARICOM, 1985-2003 ….................................................... 7

2. Survey of Selected Empirical Investment Studies Based on Jorgenson (1963) ................ 8

3. Survey of Empirical Investment Studies of Low-/Middle-Income Countries ................... 10

4. Interest Rates, Tax Rates, and Changes in the Cost of Capital_Example....................... 26

Figures

1. GDP Growth and Gross Investment-to-GDP Ratios, 1995-2004 .................................... 4

2. Investment Trends in the CARICOM Area-Three-Year Moving Averages ..................... 6

3. Caribbean: Private Investment Rate and Economic Depreciation, 1985-2004 ................ 16

4. Caribbean: Financing Cost of Capital, 1980-2004 ....................................................... 17

5. Estimated Debt-to-Capital Ratios for Private Domestic Investors (Percent) .................... 19

6. Components of Weighted-Average Real Cost of Capital ............................................... 19 
Appendix: Data Sources and Estimates

A. Capital Stock Data—Issues and Measurement ...................................................... 33

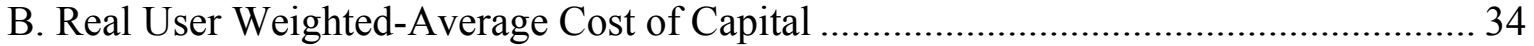

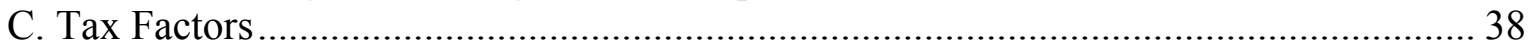

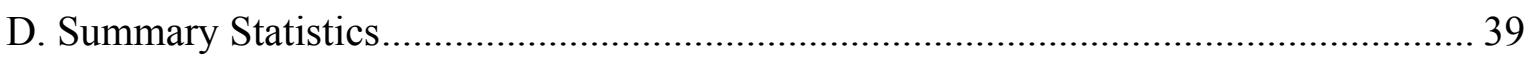

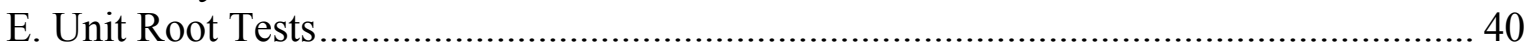

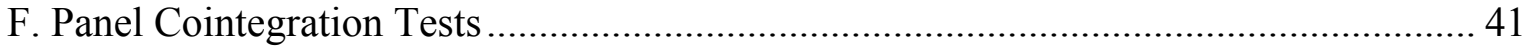

G. GMM Regression Results for the Investment Function-Including the Tax Factor..... 42

H. GMM Regression Results for the Investment Function-Excluding the Tax Factor.... 43

I. GMM Regression Results for the Investment Function-Using Real Interest Rates .... 44 


\section{INTRODUCTION}

Investment as a share of GDP is relatively high from a global perspective in many member countries of the Caribbean Community and Common Market (CARICOM). ${ }^{2}$ The region has experienced a significant amount of public sector investment and foreign direct investment (FDI) — particularly in the tourism sector — over many years. Despite this gross capital accumulation, GDP growth has been disappointingly low for many Caribbean countries (Figure 1). There are a number of possible explanations. First, the productivity of this additional capital may be low; indeed, previous work suggests that the return on public investment is less than on private investment (Khan and Kumar 1997; Bouton and Sumlinski, 2000). Second, the multipliers of this investment may be weak. For example, there may be few linkages between the foreign-owned capital stock (such as resort hotels), and the domestic economy. Alternatively, there may be crowding out of domestic private investors.

Figure 1: GDP Growth and Gross Investment-to-GDP Ratios, 1995-2004 1/

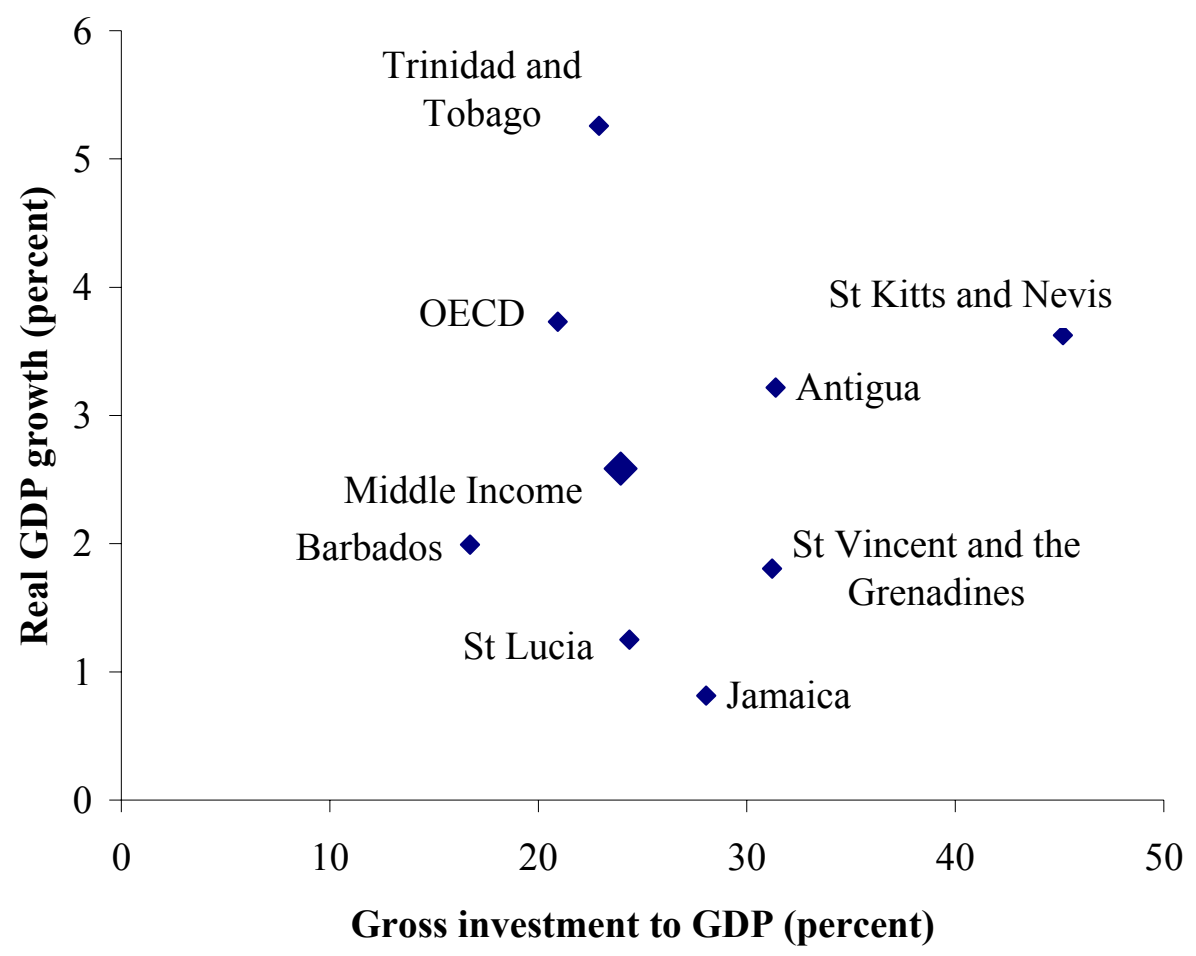

Sources: World Bank; IMF; and author's calculations.

1/ Unweighted arithmetic average of constant price GDP annual growth rates.

\footnotetext{
${ }^{2}$ CARICOM comprises 15 member states and five associate members. The subjects of this study are seven CARICOM member states: Antigua and Barbuda, Barbados, Jamaica, St. Lucia, St. Kitts and Nevis, St. Vincent and the Grenadines, and Trinidad and Tobago.
} 
One area that has not received as much attention in the literature is private domestic investment (PDI), which could prove to be one important factor to unlock growth. If PDI were to increase, then the returns to capital spending by public agencies may also increase. ${ }^{3}$ PDI could also improve the linkages between the domestic economy and foreign-owned capital. If PDI could potentially play an important role in driving growth, what factors might induce it to increase?

The objective of this paper is to assess the factors that might affect the level of PDI. The main focus will be on the cost of capital, which includes the cost of debt, equity, and the impact of taxes. In addition, there are other structural factors one might suggest, particularly for less developed countries. These include governance and financial sector regulation (Rama, 1994). There are two reasons why such factors are not a focus in this paper. First, governance indicators for the CARICOM countries in our sample are in the upper quartile of their income groups; compared to a low- to middle-income peer group, governance standards are relatively high. This suggests that governance may be less important than in low-income countries, where they have been extensively studied. ${ }^{4}$ Second, such factors, particularly related to financial sector regulation, are difficult to measure or are simply unobservable.

Using a new richer dataset, the empirical work carried out in this paper shows that PDI is sensitive to the cost of capital (CoC) in the region. PDI is unresponsive to public investment or FDI. As a result, public policy should focus on the cost of capital as a means of raising PDI. For example, across the Eastern Caribbean Currency Union (ECCU) corporate tax policy may be regarded as opaque and highly discretionary. ${ }^{5}$ It likely penalizes domestic investors at the expense of foreign investors through the distribution of inefficient tax concessions. Rebalancing tax policy could reduce the $\mathrm{CoC}$ for domestic investors. Another example is the effect policy might have on real interest rates. Reducing crowding out of domestic investors or addressing structural issues in the financial sector could allow the $\mathrm{CoC}$ to decline.

The paper proceeds as follows. Section II describes recent trends in investment across our Caribbean sample countries. Section III provides a brief review of relevant literature. Section IV describes the basic model that forms the basis of the estimations. Section V provides detail on the new data set used, while Section VI highlights important estimation issues.

\footnotetext{
${ }^{3}$ The interaction between private and public investment in developing countries is complex. The empirical literature has provided ambiguous results. For example, a survey by Everhart and Sumlinski (2001) shows that the literature is almost evenly split on whether public investment crowds in or crowds out the private sector.

4 The average World Bank Governance Indicators for this paper's sample countries (with the income group comparator average in parentheses), in terms of mean percentile rank over 1996-2004 are: 74 (61) for voice and accountability; 65 (61) for political stability; 58 (57) for government effectiveness; 65 (60) for regulatory quality; 62 (60) for rule of law; and 63 (58) for corruption.

${ }^{5}$ The ECCU in this paper refers to the six independent countries that comprise the Eastern Caribbean Currency Union: Antigua and Barbuda, Dominica, Grenada, St. Kitts and Nevis, St. Lucia, and St. Vincent and the Grenadines.
} 
Section VI shows the results, and Section VIII concludes. The Appendix provides more detail on the data.

\section{TRENDS IN REGIONAL INVESTMENT ${ }^{6}$}

Investment-to-GDP ratios in the larger CARICOM countries-Barbados, Jamaica, and Trinidad and Tobago - are close to the middle-income average of 20-25 percent. For the smaller ECCU countries, the ratio is much higher. In terms of the trend over time, compared to the 1980-95 period, the total investment-to-GDP ratio has increased. However, as Figure 2 shows, the share of PDI in the total has generally declined.

Figure 2: Investment Trends in the CARICOM Area-Three-Year Moving Averages 1/

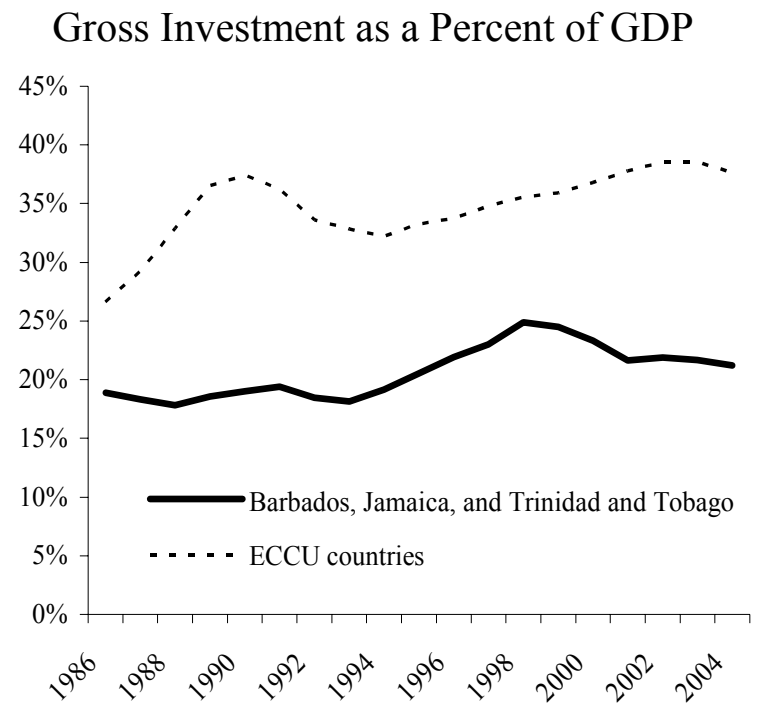

Gross PDI as a Percent of Gross Investment

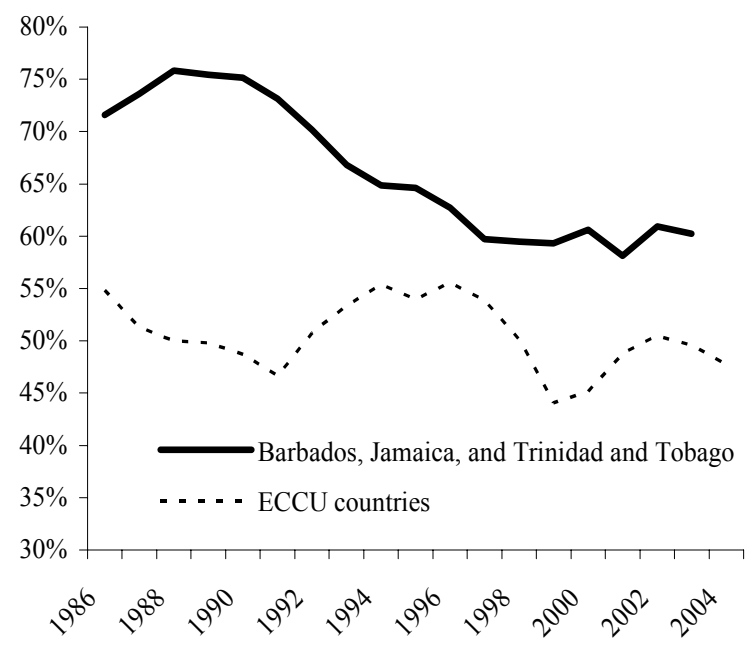

Source: National authorities; IMF; and author's calculations.

$1 /$ Unweighted averages of the investment ratios for the countries in each group.

2/ ECCU countries include Antigua and Barbuda, St. Kitts and Nevis, St. Lucia, and St. Vincent and the Grenadines.

FDI has been the real investment success story in the region. Table 1 hides many country details, particularly in terms of trends in public investment. However, two clear patterns emerge. First, the region appears to have been relatively successful in attracting foreign investors. The growth in the tourism sector is likely to have played an important part in this trend. Second, PDI has either remained stagnant or has fallen as a share of GDP.

\footnotetext{
${ }^{6}$ This section provides an overview of the basic data. Section V will provide details on the new data used for this study.
} 
Table 1. Gross Investment across CARICOM, 1985-2003 (Percent of GDP) 1/2/ 3/

(Percent of GDP)

\begin{tabular}{lcccc}
\hline & \multicolumn{4}{c}{ Period average } \\
& $\mathbf{1 9 8 5 - 8 9}$ & $\mathbf{1 9 9 0 - 9 4}$ & $\mathbf{1 9 9 5 - 9 9}$ & $\mathbf{1 9 9 9 - 2 0 0 3}$ \\
\hline $\begin{array}{l}\text { Middle-income countries } \\
\text { Gross investment }\end{array}$ & 23.3 & 23.7 & 24.0 & 23.7 \\
& & & & \\
Barbados, Jamaica, Trinidad \& Tobago & & & \\
Gross investment & 18.5 & 19.2 & 23.5 & 21.8 \\
$\quad$ Central govt & 4.1 & 3.2 & 4.4 & 2.8 \\
FDI & 0.7 & 3.0 & 4.9 & 6.3 \\
PDI & 13.8 & 13.0 & 14.2 & 12.5 \\
ECCU countries & & & & \\
Gross investment & 32.9 & 33.2 & 35.4 & 38.1 \\
Central govt & 7.1 & 6.2 & 6.2 & 6.6 \\
FDI & 9.3 & 9.8 & 11.7 & 12.4 \\
PDI & 9.3 & 9.8 & 11.7 & 12.4 \\
\hline
\end{tabular}

Source: National authorities; IMF; World Bank; and author's calculations.

1/ Unweighted averages of the current price investment ratios for the countries in each group.

2/ Data end at 2003 as this is the last year in which data was available for all countries.

3 / Private domestic investment (PDI) also includes investment by public enterprises.

\section{LITERATURE REVIEW}

\section{A. Neoclassical Aggregate Capital Stock Models}

The investment model in this paper is based on the neoclassical framework first set out by Jorgenson (1963) and uses the following capital stock equation. It is derived from a one period value maximization problem for the representative firm:

$$
k_{t}=\theta+y_{t}-\sigma \rho_{t}
$$

where $k$ is the log of the real optimal capital stock, $y$ is the log of real output, and $\sigma$ is the user cost elasticity of capital (UCE). This represents the sensitivity of the capital stock to the posttax Jorgensonian user cost of capital, which is denoted by $\rho$. There are important critiques of this model. Perhaps the most important is that it is not a full theory of investment, rather a theory conditional on the level of output. ${ }^{7}$ Despite its drawbacks, it remains the most

\footnotetext{
${ }^{7}$ Other major criticisms include: (i) output may be a proxy for liquidity factors such as cashflow;

(ii) expectations are implicitly modeled, rather than made explicit; and (iii) the model is frictionless, with no
} 
practical model for estimation in middle-income countries. More rigorous alternatives require some measure of investors' expectations, typically extracted from liquid capital markets. This is a resource not typically available in the Caribbean. ${ }^{8}$ This model also has an empirical record that compares well to its competitors, particularly Tobin's $q$. In many studies, the cost of capital has been found to be a significant explanatory factor driving investment, in contrast to many estimates of $q$.

Table 2. Survey of Selected Empirical Investment Studies Based on Jorgenson (1963)

\begin{tabular}{|c|c|c|c|}
\hline Study & Sample & Method & Main Result \\
\hline $\begin{array}{l}\text { Eisner and Nadiri } \\
\text { (1968) }\end{array}$ & U.S. data over 1929-63 & Neoclassical model. & $\begin{array}{l}\text { Estimate the user cost elasticity } \\
\text { (UCE) to be in the range }-0.16 \text { to } \\
-0.33\end{array}$ \\
\hline $\begin{array}{l}\text { Chirinko survey } \\
\text { (1993) }\end{array}$ & Review of the literature. & $\begin{array}{l}\text { Various but mostly the } \\
\text { neoclassical model. }\end{array}$ & UCE in the range of 0.0 to -0.3 \\
\hline $\begin{array}{l}\text { McKenzie and } \\
\text { Thompson (1997) }\end{array}$ & $\begin{array}{l}\text { Using used sectoral aggregate } \\
\text { Canadian data from the 1973- } \\
93 \text { period. }\end{array}$ & $\begin{array}{l}\text { Investment rate regressed on } \\
\text { annual percentage changes on } \\
\text { the cost of capital and output. }\end{array}$ & UCE around -0.03 and significant \\
\hline $\begin{array}{l}\text { Carruth, } \\
\text { Dickerson, and } \\
\text { Henley (2000) }\end{array}$ & $\begin{array}{l}20 \text { years of quarterly U.K. } \\
\text { data through } 1995\end{array}$ & $\begin{array}{l}\text { ECM used to estimate a long-run } \\
\text { relationship for investment, } \\
\text { output, profits, interest rates, and } \\
\text { gold. }\end{array}$ & Estimate a UCE around -0.03 \\
\hline $\begin{array}{l}\text { Tevlin and Whelan } \\
\text { (2003) }\end{array}$ & $\begin{array}{l}\text { Disaggregated U.S. data for } \\
1950-97\end{array}$ & & $\begin{array}{l}\text { UCE significant at }-0.18 \text { and }-1.59 \\
\text { for the computer sector }\end{array}$ \\
\hline Goolsbee (2000) & $\begin{array}{l}\text { U.S. sectoral data over } 1963- \\
1988 \text { on } 22 \text { classes of } \\
\text { equipment. }\end{array}$ & & Estimated a UCE around -0.10 \\
\hline $\begin{array}{l}\text { Ellis and Price } \\
(2004)\end{array}$ & $\begin{array}{l}\text { U.K. quarterly data over } \\
\text { 1972-2004. }\end{array}$ & $\begin{array}{l}\text { VECM with multicointegrating } \\
\text { vectors. }\end{array}$ & Estimated a UCE around -0.48 \\
\hline $\begin{array}{l}\text { McMahon, Sterne, } \\
\text { and Thompson } \\
(2005)\end{array}$ & $\begin{array}{l}\text { Panel of OECD countries over } \\
\text { 1980-2000. Quarterly data } \\
\text { disaggregated for the ICT and } \\
\text { non-ICT sectors }\end{array}$ & $\begin{array}{l}\text { ECM estimated using SUR. } \\
\text { Dynamics were country-specific, } \\
\text { but the long-run relationship was } \\
\text { common. }\end{array}$ & $\begin{array}{l}\text { UCE for investment to be } \\
\text { insignificantly different from zero } \\
\text { for the full sample, but }-1.3 \text { for the } \\
\text { ICT sector }\end{array}$ \\
\hline
\end{tabular}

explicit role for adjustment costs. For a full survey of implicit neoclassical investment models, see Chirinko (1993) and Caballero (1995).

${ }^{8}$ The more theoretically rigorous $q$-model typically relies on the ability of the econometrician to extract expectations regarding the marginal productivity of capital by imposing a linear homogeneous assumption on production and adjustment cost functions (Hayashi, 1982) and then using equity and debt market valuations. 


\section{B. Empirical Applications to Middle-Income Economies}

A large literature has flourished in the area of FDI and developing countries, but less attention has been paid to domestic investment. There have also been few applications of the $\mathrm{CoC}$ model to middle-income or developing countries. In many of these cases, the line of inquiry has been economic or political instability, commodity price shocks, and debt overhang. The impact of public investment has also been a focus, although the results have been ambiguous. ${ }^{9}$

Cost variables have often been proxied by real interest rates, rather than a more comprehensive user cost variable. Specifications have varied widely and, in many cases, have not been derived from an explicit value maximization problem. Where private investment functions have been estimated, they have tended to include FDI and have typically been ad hoc, atheoretical models

There have also been few attempts to compare the cost of capital across middle-income countries. One example that focused only on the financing cost is provided by Estache and Pinglo (2004). Using a panel of 120 firms operating in infrastructure sectors across 31 lowand middle-income countries, the nominal $\mathrm{CoC}$ estimate derived was based on the standard weighted average method. ${ }^{10}$ For $1998-2002$, the estimated financing CoC for middle-income and low-income countries was around 11 and 14 percent, respectively.

Table 3 summarizes the results of recent studies on the sensitivity of investment to the cost of capital, with a particular focus on middle-income countries.

\footnotetext{
${ }^{9}$ For examples of this approach for Latin America see Cardoso (1994) and for Africa see Oshikoya (1994) and Dehn (2000).

${ }^{10}$ Estache and Pinglo (2004) used the statutory corporate income tax rate and did not include the effects of tax credits or the present value of future capital allowances. Real economic depreciation was also not included as a component of the cost of capital. In contrast to the present paper, which uses the current three-month eurodollar interest rate as the risk-free return, the risk-free rate used was the geometric average of long-term U.S. government bonds over a 40-year period. The cost of debt was estimated using a U.S. dollar risk-free rate, a corporate credit spread, a country default credit spread, and statutory tax rates. The cost of equity used a fixed equity risk premium for the U.S. market, predicted capital asset pricing model betas for U.S. companies operating in the same sectors, and an additive country risk premium, again implied by default credit spreads.
} 
Table 3. Survey of Empirical Investment Studies of Low-/Middle-Income Countries

\begin{tabular}{|c|c|c|c|}
\hline Study & Sample & Method & Main Result \\
\hline $\begin{array}{l}\text { Larrain and } \\
\text { Vergara (1993) }\end{array}$ & $\begin{array}{l}\text { Four middle-income East } \\
\text { Asian countries over } \\
\text { 1975-88 }\end{array}$ & $\begin{array}{l}\text { Private investment-to- } \\
\text { GDP ratio as dependent } \\
\text { variable }\end{array}$ & $\begin{array}{l}\text { Coefficient of }-0.02 \text { on real } \\
\text { interest rates. Coefficient of }-0.15 \\
\text { on external debt-to-GDP and } 0.18 \\
\text { on public investment. }\end{array}$ \\
\hline $\begin{array}{l}\text { Mataya and } \\
\text { Veeman (1996) }\end{array}$ & Malawi & $\begin{array}{l}\text { General model that did } \\
\text { not account for } \\
\text { regressor endogeneity. }\end{array}$ & User cost elasticity of -0.8 \\
\hline $\begin{array}{l}\text { Bende-Nabende } \\
\text { and Slater (2003) }\end{array}$ & $\begin{array}{l}\text { East Asian sample from } \\
\text { 1971-99 }\end{array}$ & $\begin{array}{l}\text { Private investment-to- } \\
\text { GDP ratio as dependent } \\
\text { variable }\end{array}$ & $\begin{array}{l}\text { Inversely related to real interest } \\
\text { rates and public investment } \\
\text { (crowding out). Positive effect } \\
\text { from FDI (crowding in). }\end{array}$ \\
\hline $\begin{array}{l}\text { Lederman, } \\
\text { Menendez, Perry, } \\
\text { and Stiglitz (2003) }\end{array}$ & Mexico, 1981-2000 & $\begin{array}{l}\text { GMM model with } \\
\text { investment-to-GDP as } \\
\text { dependent variable. }\end{array}$ & $\begin{array}{l}\text { Coefficient on domestic real } \\
\text { interest rates significant at }-0.06 \text {. } \\
\text { Evidence of credit rationing. }\end{array}$ \\
\hline Vergara (2004) & Chile, 1975-2003 & $\begin{array}{l}\text { Private investment-to- } \\
\text { GDP ratio as dependent } \\
\text { variable }\end{array}$ & $\begin{array}{l}\text { Coefficient on tax factor }-0.28 \text {. } \\
\text { Real interest rates insignificant. } \\
\text { External debt had a negative } \\
\text { effect. }\end{array}$ \\
\hline $\begin{array}{l}\text { Chari and Henry } \\
(2004)\end{array}$ & $\begin{array}{l}\text { Panel of } 369 \text { emerging } \\
\text { market infrastructure } \\
\text { firms with a domestic } \\
\text { stock exchange listing }\end{array}$ & $\begin{array}{l}\text { Effect of liberalization } \\
\text { in domestic stock } \\
\text { markets }\end{array}$ & $\begin{array}{l}\text { Investment positively affected by } \\
\text { postliberalization boom in stock } \\
\text { prices (and reduction in cost of } \\
\text { equity). }\end{array}$ \\
\hline
\end{tabular}

\section{Weaknesses of the Neoclassical Model}

A range of factors may account for a small estimated UCE using aggregate data. ${ }^{11}$ Many of these are likely to apply in the Caribbean. One important issue for the Caribbean is measurement error in the key variables, which will tend to bias the estimated coefficient toward zero. One potentially important source of error in the Caribbean might be the use of statutory tax rates in the calculation of the marginal effective tax rate. There is a high prevalence of tax concessions in the region, although they are mostly offered to foreign investors (Chai and Goyal, 2005; Sosa, 2006). Changes in the effective tax rate are unobservable in many countries since the practice of publishing tax incentives offered has been introduced only recently. To assess the impact of taxes, estimates are provided with and without the tax factor.

\footnotetext{
${ }^{11}$ As noted above, the user cost elasticity (UCE) measures the sensitivity of the capital stock to the cost of capital $(\mathrm{CoC})$.
} 
Other problems are less Caribbean-specific. These include, but are not limited to: credit market frictions that impose cashflow constraints upon firms; ${ }^{12}$ irreversibility of investment and the option value of delay (Pindyck, 1991); imperfect competition in output markets (Schiantarelli and Georgoutsos, 1987); learning-from others; ${ }^{13}$ and tax-exhaustion for startups with negative income, prohibiting the use of tax deductions (Gendron, Anderson, and Mintz, 2003). For small firms and entrepreneurs, it may be some time before the initial investment yields a positive cashflow. This implies that the firm is unable to enjoy the benefit of tax deductions that apply to investment activity.

\section{A Basic InVESTMent Model}

The following two sections provide some theoretical background for the model to be estimated in Section V. Despite a voluminous theoretical literature, there is no consensus on the appropriate form of an empirical investment equation, particularly for developing economies (Rama, 1994). Much of the focus in this paper is on the cost of capital. The HallJorgenson approach allows explicit derivation of a cost term.

The representative firm's problem is to maximize the present value of all future cashflows. One important point to note in this model is that there are no capital stock adjustment costs. ${ }^{14}$ The firm's problem is then to maximize a value function:

$$
V_{t}=E_{t}\left\{\sum_{s=t}^{\infty}(1+r)^{t-s}\left[(1-u) p_{s} F\left(K_{s}^{P}, K_{s}^{G} K_{s}^{F}, N_{s}\right)-w_{s} N_{s}-(1-\Gamma)(1+\tau) p_{s}^{K} I_{s}^{P}\right]\right\}
$$

This is subject to the usual capital accumulation constraint. It is assumed that private investment $\left(I^{P}\right)$ only becomes useful private capital $\left(K^{P}\right)$ with a one-period lag:

$$
K_{s+1}^{P}=I_{s}^{P}+(1-\delta) K_{s}^{P}
$$

It is assumed that the firm's production function includes both public $\left(K^{G}\right)$ and foreign $\left(K^{F}\right)$ capital as arguments. This model is being applied here to small open economies. Consequently, the effect of personal taxation of dividend flows and capital gains is ignored. ${ }^{15}$

\footnotetext{
12 See Fazzari, Hubbard, and Petersen (1988); Devereux and Schiantarelli (1989); and Hoshi, Kashyap, and Scharfstein, (1991).

${ }^{13}$ See Caplin and Leahy (1994); Chetty (2004); and Cunningham (2004).

${ }^{14}$ This is one crucially important departure from the $q$-model of investment. The perceived existence of adjustment costs often emerges from empirical applications of the neoclassical model through serial correlation in residual terms. See Section $\mathrm{V}$ for details.

${ }^{15}$ As Boadway and Shah (1995) argue, for a small open economy, the savings and investment decisions may be assumed to be separable, implying that personal taxation affects the incentive to save, but has no relevance for the investment decision.
} 
Across most of the region, the tax authorities apply the capital allowance to a capital base that is eroded exponentially. Then the present value of tax benefits may be written as: ${ }^{16}$

$$
\Gamma=\eta+u \tilde{\alpha}+(1-\theta \eta-\omega \widetilde{\alpha}) \sum_{v=t+1}^{\infty}(1+r+\alpha)^{t-v} u \alpha
$$

There are some examples, such as Barbados, where the tax authorities apply the allowance to a capital base that is subject to straight-line erosion. Present value of deductions may then be written as:

$$
\Gamma=\eta+u \tilde{\alpha}+(1-\theta \eta-\omega \widetilde{\alpha}) \sum_{v=t+1}^{T}(1+r)^{t-v} u T^{-1}
$$

where in the above equations:

$r \equiv$ nominal weighted average financing cost of capital (debt and equity)

$u \equiv$ corporate tax rate

$p \equiv$ output price

$p^{K} \equiv$ capital goods price

$w \equiv$ nominal wage

$N \equiv$ labor

$\Gamma \equiv$ present value of tax benefits for investment

$\eta \equiv$ investment tax credit rate, in the form of a rebate/direct grant

$\theta \equiv$ proportion of tax credit that reduces the tax-depreciable capital base

$\widetilde{\alpha} \equiv$ immediate capital allowance rate

$\omega \equiv$ proportion of the immediate capital allowance that reduces tax-depreciable capital ${ }^{17}$

$\tau \equiv$ tariff on imported capital equipment

$\delta \equiv$ economic (real) depreciation rate

$\alpha \equiv$ tax depreciation/ capital allowance rate

$T \equiv$ assumed useful life if capital equipment for tax deduction purposes.

It will be assumed that the firm's production function is linearly homogeneous and that it is using the optimal labor input and faces competitive output markets. ${ }^{18}$ Firms will choose the

\footnotetext{
${ }^{16}$ This representation does not account for nondepreciable assets such as land.

${ }^{17}$ Note that when $\omega=0$, the allowance upon purchase of the capital equipment is in the form of a pure tax credit, with no impact upon the depreciable base used for future depreciation/ allowances. If $\omega=1 / u$, then the immediate allowance fully reduces the base.

${ }^{18}$ This assumption may be challenged in the Caribbean for those industries that enjoy special protection within the CARICOM area. There are a number of domestically owned industries that benefit from a relatively high common external tariff and nontariff barriers (often in the form of import licences) that are applicable to intraCARICOM trade. As a result, such industries might possess a nontrivial amount of market power. In this case, the price elasticity of demand would enter the first-order condition and would increase the user cost of capital. Schiantarelli and Georgoutsos (1987) show how to incorporate monopolistic competition into an empirical investment equation.
} 
state variable (the firm's own capital) to maximize this value. Rearranging the first-order condition and denoting the real percent change in the price of capital as $q$ and the inflation effect $\pi$, this can be written as:

$$
E_{t}\left\{p_{t+1}\right\} F_{K}=\frac{(1-\Gamma)(1+\tau)}{(1-u)}\left[p_{t}^{K}\left(r+\delta\left(1+E_{t} q\right)\left(1+E_{t} \pi\right)\right)-p_{t}^{K}\left(1+E_{t} q\right)\left(1+E_{t} \pi\right)+p_{t}^{K}\right]
$$

It is common in the literature to let the expected real change in the capital goods be equal to zero. This implies that the first-order condition can be expressed as the marginal product of capital equal to the post-tax user cost of capital, denoted by $P$ :

$$
F_{K}=\frac{p_{t}^{K}}{p_{t}\left(1+E_{t} \pi\right)} \frac{(1-\Gamma)(1+\tau)}{(1-u)}\left(r-E_{t} \pi+\delta\left(1+E_{t} \pi\right)\right)=P_{t}
$$

The final stage is to assume a relatively general CES form for the production function. This allows the extraction of optimal $K$. Denote the log of the post-tax cost of capital as $\rho$ and the elasticity of capital to labor as $\sigma$. Then the first-order condition can be expressed as:

$$
k_{t}=a+y_{t}-\sigma \rho_{t}
$$

This basic equation is used as the foundation of all specifications in the empirical work that follows.

\section{DAta}

As noted by Hicks (1981), "the measurement of capital is one of the nastiest jobs that economists have set to statisticians." Since this describes only one of our variables, it is clear that one of the more challenging aspects of estimating investment models is the selection and treatment of data. In this section, some of the more pertinent issues are addressed. The details are provided in the Appendix. The key variables used in the estimation were the real capital stock, real output, and the user cost of capital.

Measures of the cost of capital and real investment depend upon the price of capital goods and estimates of real economic depreciation. Across much of the Caribbean, data on both are unavailable. Using GDP deflators or consumer prices to deflate nominal capital expenditure is likely to introduce significant measurement error. To overcome this gap, use was made of the OECD STAN database, which provides investment deflators and depreciation rates for the capital used by sectors across countries. Global sector aggregates were estimated from STAN. These were then applied to each country by weighting each sector's real value added 
to obtain country-specific aggregates. The critical assumption here is that the region imports capital goods at the world price and experiences the same rate of depreciation as elsewhere. ${ }^{19}$

The capital stock was estimated using the standard accumulation identity and the method first developed by Nehru and Dhareshwar (1993), which is described in the Appendix. The effect of natural disasters, an important factor for the region, was included. ${ }^{20}$ These are clearly subject to measurement error. However, account has to be taken of disasters as they are a factor that, in the ECCU region, have caused damage equivalent to around 2 percent of GDP in recent years (Rasmussen, 2004). Dummy variables for the year of the disaster, plus the following year, were also included, although for the most extreme outliers, the observations were removed. $^{21}$

An interesting way to view this data is to compare the private domestic investment rate to economic depreciation $(\delta)$. Abstracting from the effect of natural disasters, this drives the growth in the private capital stock; whenever the investment rate is greater than depreciation, the capital stock is growing in real terms. That is:

$$
\frac{\Delta K_{t+1}^{P}}{K_{t}^{P}}=\frac{I_{t}^{P}}{K_{t}^{P}}-\delta .
$$

Figure 3 shows this difference for the sample Caribbean countries. As can be seen, the investment rate is volatile, reflecting the lumpiness of investment, but also the effect of natural disasters which are not shown as part of depreciation here.

Figure 4 shows the financing cost of capital, reflecting debt, equity, depreciation, and tax. ${ }^{22}$ In the absence of a deep and liquid stock market, estimates for the cost of debt and equity from standard approaches, such as the capital asset pricing model (CAPM), are difficult to obtain. There is also no consensus on what assets should be used when estimating the cost of

\footnotetext{
${ }^{19}$ There is a case for considering a higher rate of depreciation in the region, due to climactic factors and the potential for a lower level of ongoing maintenance. In the absence of any empirical evidence quantifying such effects, such considerations were not included. Unless the region-specific depreciation differentials change over time, this will not affect empirical estimations.

${ }^{20}$ This factor was estimated using the EM-DAT database and data from the regional emergency management agency (CDERA).

${ }^{21}$ The dummies account for the likely short-run impact that insurance and aid flows might have on output, but not necessarily the capital stock, in the aftermath of a disaster. See the Appendix for details of the outliers removed.

22 Trinidad and Tobago is shown in place of Jamaica in this panel of charts. This is because it is an interesting case where the tax factor has declined significantly.
} 
equity. To overcome the lack of financial markets, weighted average country CAPM betas were constructed using global asset prices. ${ }^{23}$

Notice that the cost of capital has been rising across much of the region in recent years. The increase in the depreciation rate (largely related to an increasing weight for technology equipment) has not been offset by interest rates or the cost of equity. The average financing cost of capital for the sample countries in 2004 was 15.2 percent. Using the same methods, the approximate cost of capital for U.S. corporations in 2004 was 8.2 percent. $^{24}$

\footnotetext{
${ }^{23}$ The CAPM beta represents the undiversifiable systemic risk of the investing in the country. Given that the sample countries run open capital accounts, it is assumed that all idiosyncratic risk may be diversified away.

${ }^{24}$ This used the S\&P 500 debt-to-assets ratio, an average BAA corporate bond yield of 6.4 percent, the statutory 35 percent corporate tax rate, an approximate tax factor of 1.14 , and an equity risk premium over the U.S. 10 -year Treasury note of 2.8 percent.
} 
Figure 3. Private Investment Rate (I/K) and Economic Depreciation (Dep.) (local currency 2000 prices, percent) $1 /$

Antigua and Barbuda

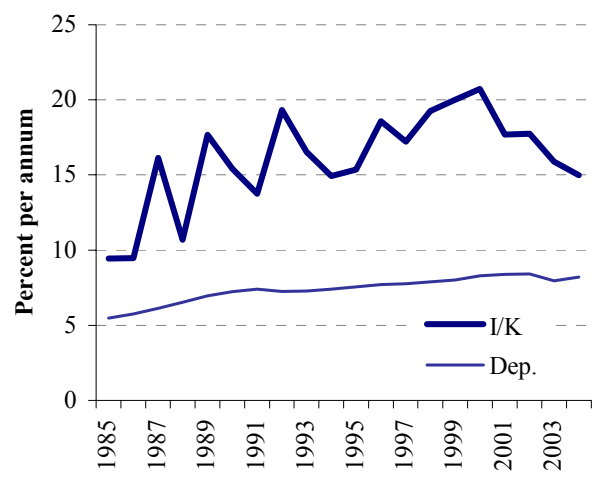

St. Lucia

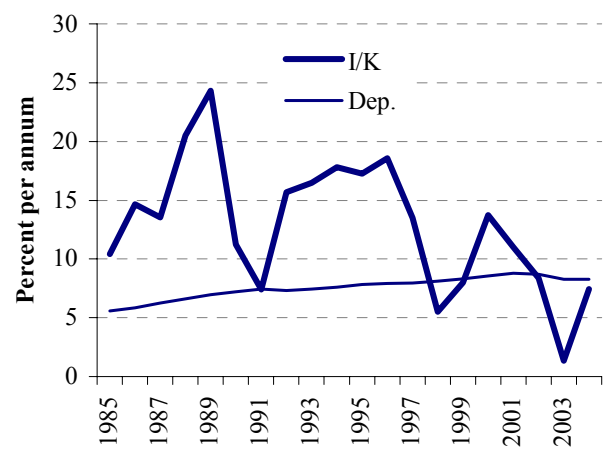

Barbados

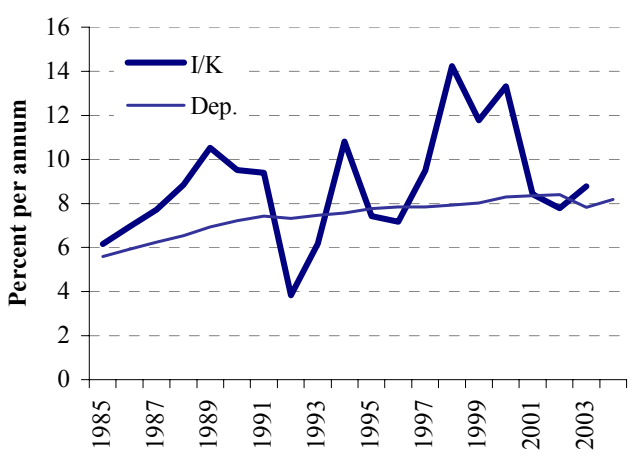

St. Kitts and Nevis

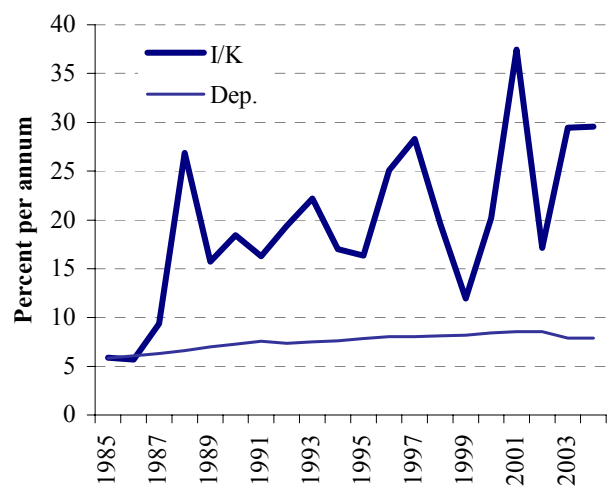

St. Vincent and the Grenadines

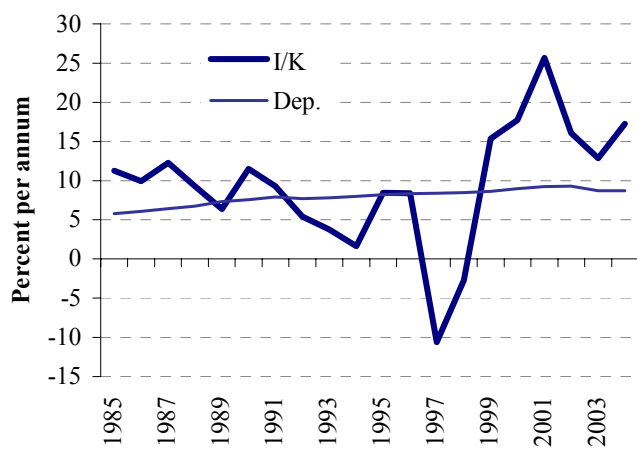

Jamaica

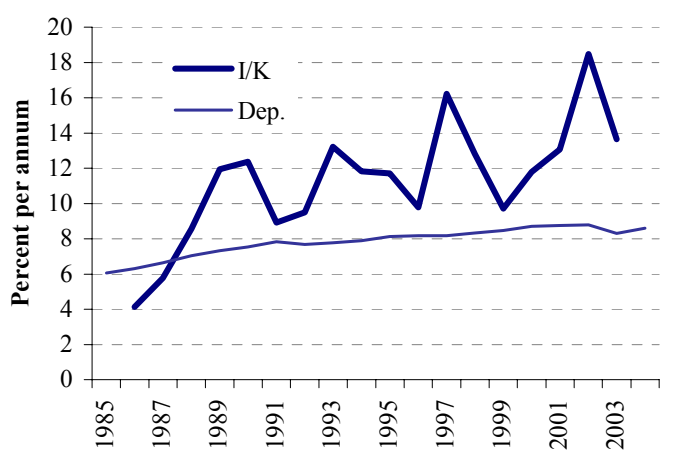

Sources: National authorities; Organization for Economic Cooperation and Development; and author's calculations.

1/ I and K deflated by the local currency capital goods deflator. Excludes effects of natural disasters. 
Figure 4. Sample Countries: Financing Cost of Capital, 1980-2004 1/

(Percent)

Antigua and Barbuda

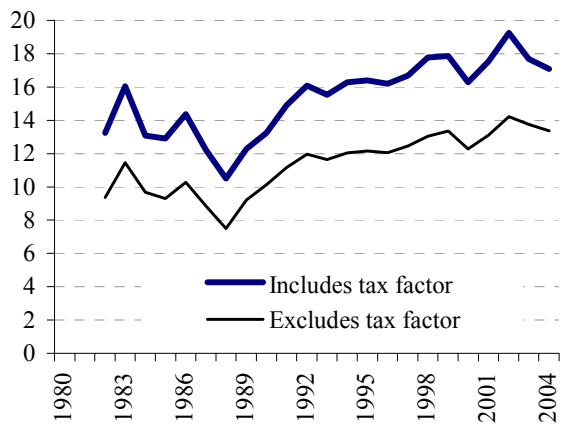

St. Lucia

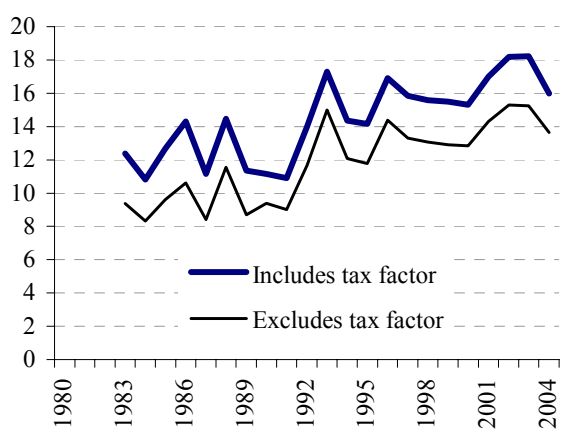

Barbados

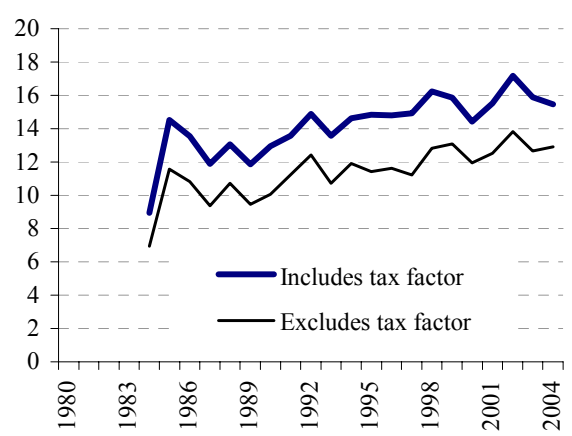

St. Kitts and Nevis

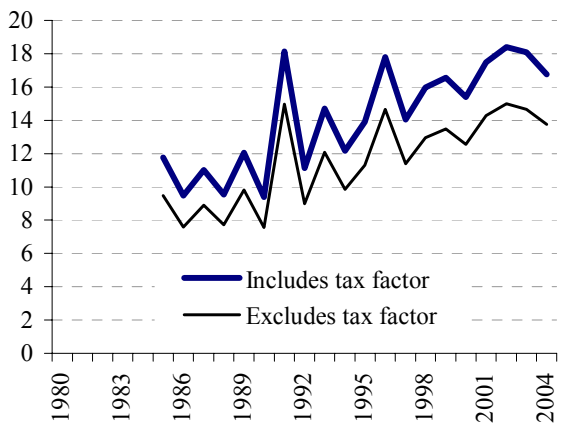

St. Vincent and the Grenadines

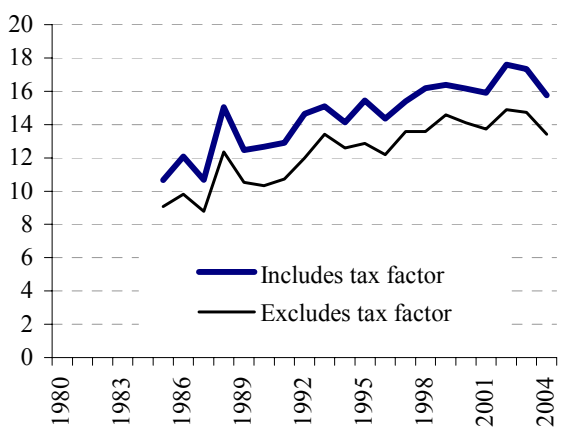

Trinidad and Tobago

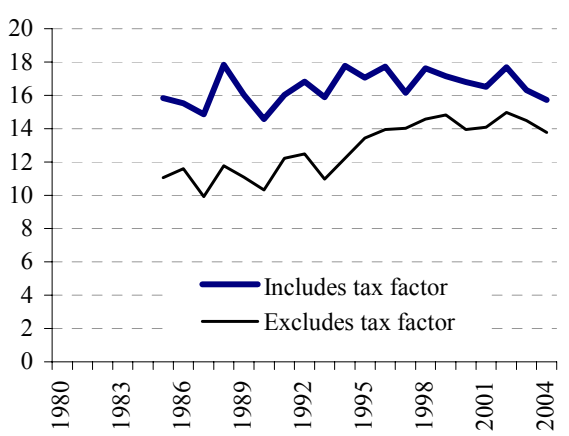

Sources: National authorities; IMF; Organization for Economic Cooperation and Development; Datastream; Price Waterhouse; and author's calculations.

1/ Includes the cost of debt, equity, and depreciation. Trinidad and Tobago is presented in place of Jamaica. Extreme country-specific volatility in Jamaica makes it difficult to compare to regional peers. 
To construct CAPM betas for each country, the share in GDP of what might be regarded as global industries, such as tourism, mining, and energy, were used to weight the betas from the global sector equity index on the world equity market. The remainder was accounted for by the beta of the global emerging markets index. This downplays the role of countryspecific factors in determining the risk premium. This approach reflects the opportunity cost of equity capital when investors face an open capital account and are considering projects in certain industries. ${ }^{25}$ Investment opportunities in these small countries are often related to expectations regarding a key sector (e.g., tourism or energy), and this is likely to outweigh country-specific issues in many cases.

One interesting development in the regional beta has been the increasing weight of tourism and the effect this has had on risk. After the crisis of 1997-99, the systemic risk of emerging markets subsequently declined. However, this has not fully fed through to all areas of the Caribbean. One reason is that the beta of the global tourism sector rose sharply after the 9/11 terrorist attacks. Equity assets in this sector are now performing as highly leveraged plays on the overall stock market cycle. ${ }^{26}$

An interesting byproduct of this data is an estimation of the sources of finance for private domestic investors in the region. Compared with industrial country standards, the level of equity funding is high. In the case of debt financing, with most business sector borrowing in the CARICOM Caribbean taking the form of bank loans rather than tradable bonds, the nominal book value of these loans is taken as the level of debt funding. This is taken as the outstanding book value of all loans to the business sector. ${ }^{27}$ The share of equity is then the residual. ${ }^{28}$

Figure 5 shows the private sector business debt-to-capital ratio for each country. The highest is St. Kitts and Nevis (likely influenced by the sugar company, a public enterprise) and the lowest is Jamaica, which has suffered from long periods of intense real interest rate volatility. The average across the sample countries is 38 percent. This compares to the companies in the S\&P 500 U.S. equity market index, for which the debt-to-capital ratio is around 80 percent.

\footnotetext{
${ }^{25}$ For example, Caribbean investors could replicate a global sector investment by purchasing an exchangetraded fund that is indexed to a global sector benchmark.

${ }^{26}$ To assess whether the $9 / 11$ effects influenced the results, estimations included a common post-9/11 dummy variable.

${ }^{27}$ Loans to the personal sector used for the construction of property are also included because personal sector construction is typically an inextricable component of gross fixed capital formation.

${ }^{28}$ Clearly, this method assumes a market-to-book value ratio of unity and therefore does not account for intangible assets that might be recorded on the balance sheet, nor does it reflect the market value of equity, which might differ from the book value.
} 
Figure 5. Estimated Debt-to-Capital Ratios for Private Domestic Investors (Percent)

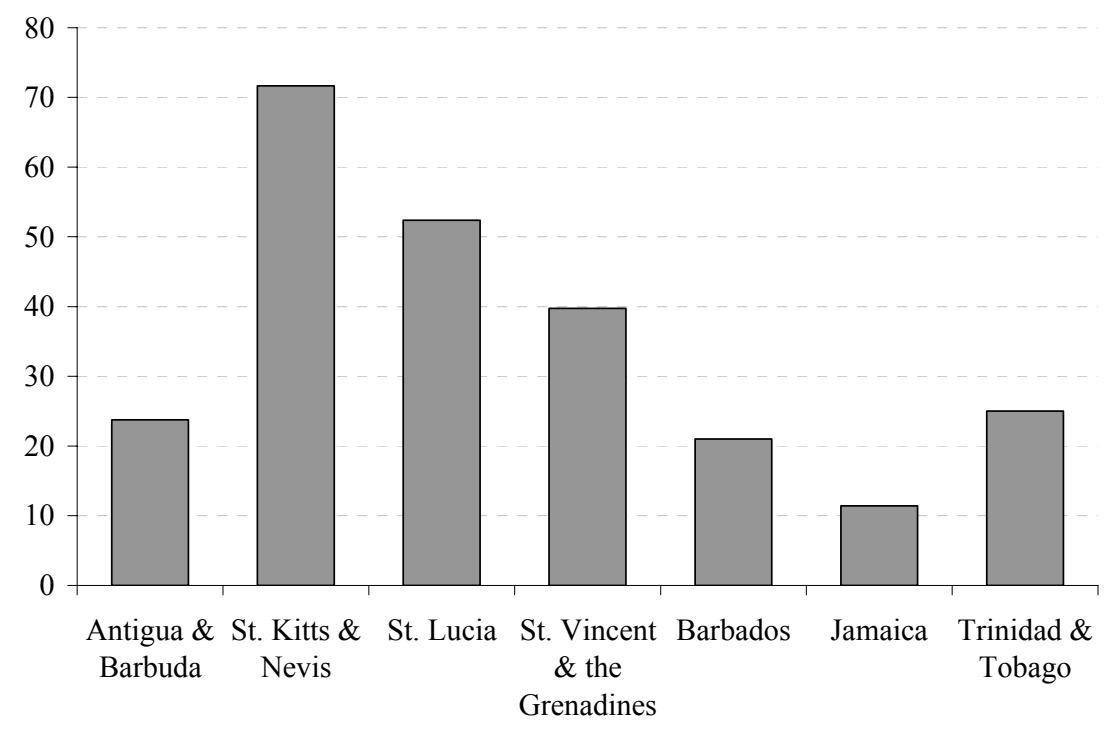

Sources: National authorities and author's estimates

Figure 6 shows how the overall $\mathrm{CoC}$ using this method compares across countries. The figures for each country have been weighted by the average source of finance. For example, the weighted cost of debt in Jamaica is very low because almost all PDI is estimated to be financed from equity (e.g., retained earnings).

Figure 6. Components of Weighted-Average Real Cost of Capital (percent, 2000-04) 1/

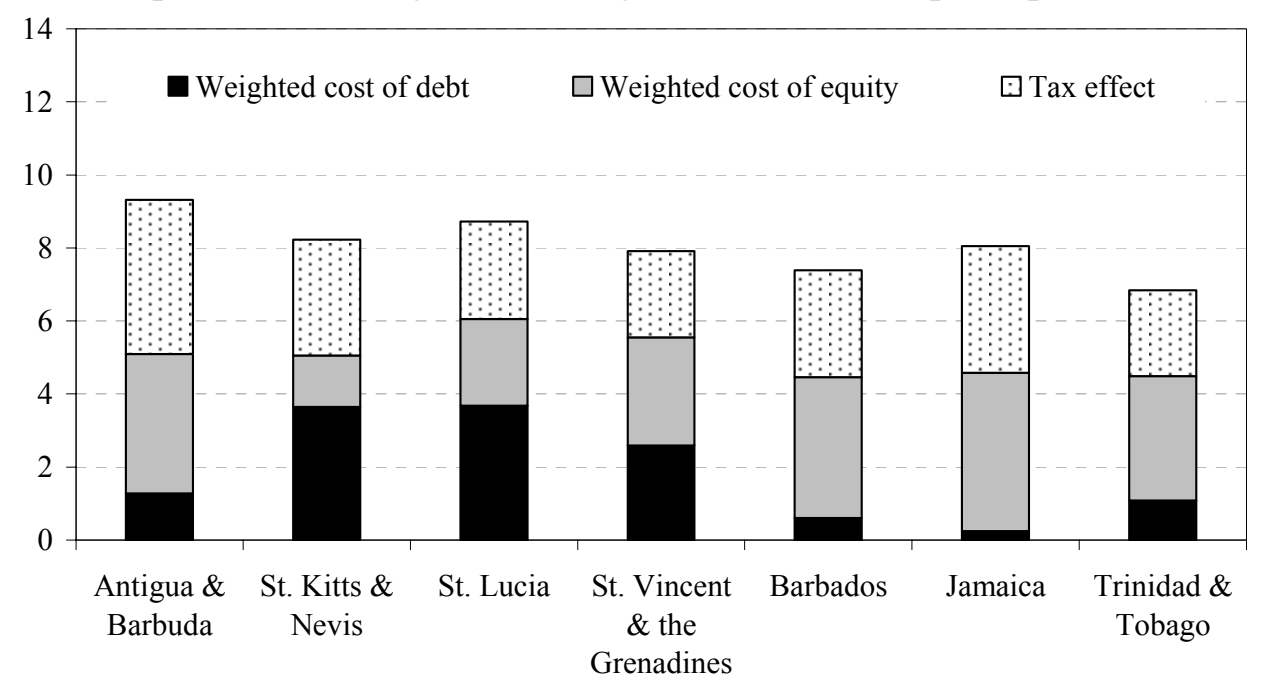

Sources: National authorities and staff estimates.

$1 /$ Contributions are weighted by the proportion of capital that has been historically financed from each source. For each country, the percentage financed by debt is: Antigua 25\%; St. Kitts and Nevis $76 \%$; St. Lucia 56\%; St. Vincent and the Grenadines 42\%; Barbados 21\%; Jamaica 11\%; and Trinidad and Tobago $25 \%$. The three-year average cost of debt for Jamaica is used due to significant volatility. The only other component excluded is economic depreciation. 


\section{ESTIMATION ISSUES}

\section{A. Sample Selection}

An unbalanced panel of seven countries using annual data with a maximum span of 1980 to 2004 was used for the estimations. For all specifications, two samples were used: (i) the full sample of seven Caribbean countries, (ii) the sample excluding Trinidad and Tobago. Each country is a "special case," but this approach was taken because of the very heavy weight of the energy sector in Trinidad's economy. ${ }^{29}$ It is likely that investment in Trinidad, both in the energy sector but also in other sectors due to the multiplier effect, may be strongly influenced by energy-specific factors. It was not possible to extricate reliably the energy sector from the aggregate data. In most cases, the results from the sample excluding Trinidad tended to be stronger.

\section{B. Stationarity}

Experience from other countries suggests that the real capital stock $K$ and real output $Y$ are both likely to exhibit trends and may be I(1) series. In theory, the real financing cost of capital should be I(0) over the very long-run. It cannot rise or fall without bound; however in panels with relatively small $T$, persistent trends in this series are often present. To test the order of integration, panel unit root tests were used for this seven-country panel. The results are shown in the Appendix. In almost all cases, it was possible to accept the null of a unit root. The exceptions are the cost of capital and real interest rates; following the literature, whenever the capital and output series are first-differenced, the cost variables will be similarly treated. In all cases, there was clear evidence that first-differenced series were stationary.

\section{Error-Correction Representation}

Following Bean (1981), much of the preceding literature has used an error-correction representation (ECM) of the optimal capital stock equation. The ECM form may be derived in the usual way for the optimal capital stock model. In general, a relationship in levels, with lags to account for potential adjustment costs slowing the rate of response, is posited:

$k_{i t}=a_{i}+\sum_{u=0}^{U} b_{i u} y_{i t-u}+\sum_{v=0}^{V} c_{i v} \rho_{i t-v}+d_{i} k_{i t-1}+e_{i t}$

Standard transformations may be applied such that the ECM is derived. For example, in the following general representation, $\theta$ denotes the adjustment coefficient to the long-run relationship, while $\Pi$ is the cointegrating vector:

\footnotetext{
${ }^{29}$ Over the sample period, it was estimated from national authority and IMF data that the value added of the energy sector averaged 28 percent.
} 
$\Delta k_{i t}=\alpha_{i}+\theta_{i} \Pi_{i t-1}+\sum_{s=1}^{T 1} \beta_{s} \Delta y_{i t-s}+\sum_{s=1}^{T 2} \chi_{s} \Delta \rho_{i t-s}+e_{i t}$

While a number of approaches that have been taken when estimating the standard ECM representation, the existence of a cointegrating relationship must first be tested. ${ }^{30}$ This is particularly important for middle-income countries. They might experience structural shifts in difficult-to-observe factors that cause long-term relationships to change. Since we are considering a panel of countries, it is appropriate to use panel-specific tests for cointegration.

\section{Testing for Cointegration}

The cointegration tests presented here are based on Pedroni's (1999) seven tests for cointegration in heterogeneous panels with multiple regressors. Four tests are based on pooling within-dimension and three are based on group means between-dimension. In general, the latter three group mean tests are preferred for this sample. They allow for full heterogeneity across the countries. This avoids imposing too many assumptions on the model at an early stage. The parametric tests are analogous to the Engle-Granger procedure, in which the residuals from a log-levels equation are tested for unit roots using the augmented Dickey-Fuller test. ${ }^{31}$ All tests are one-tailed with the group statistic distributed as a standard normal under the null of no cointegration. ${ }^{32}$

As Table 4 in the Appendix shows, it was not possible to reject the null of no cointegration at any meaningful level of significance. One possible reason for this finding is that factors outside the neoclassical model serve to transmit permanent shocks to the optimal capital stock. As discussed above, middle-income countries may be subject to a number of structural shocks related to the investment climate that are difficult to identify and may not be possible to quantify. These results suggest that it would be inappropriate to impose an ECM representation on the Caribbean sample.

\footnotetext{
${ }^{30}$ First, estimate the equation for each member separately and then examine the distribution of estimated coefficients across members (mean group estimation). Second, estimate with fixed effects but homogeneous slop coefficients using pooled panel estimators. Pesaran, Shin, and Smith (1999) suggest a pooled mean group estimator (PMG) in which the long-run coefficients are homogeneous, but the dynamics vary. They argue that it is more plausible for the long-run parameters to be the same, an assumption implicitly made throughout this paper.

${ }^{31}$ The first step in the group mean parametric tests is to strip out common time effects. Panel cointegration regressions are then estimated for each member individually, including fixed effects and heterogeneous time trends as warranted. ADF regressions are estimated for each member. Using the individual $t$-statistics for the null of no cointegration, a group test statistic is constructed, using regression specific adjustment terms.

${ }^{32}$ With the exception of the variance ratio test.
} 


\section{E. Estimation Strategy and Method}

The strategy is to estimate equation (1) as a structural model. This model is structural since it describes the economic causal relationships implied by the neoclassical model. This is not a study of short-run dynamics. With limited data and the small domestic investor population in each country, the lumpiness of investment is unlikely to offer the rich short-run dynamics of larger economies. The main costs of this approach are twofold. First, the long run will not take into account the accumulation of past investment gaps. Note that because output is a regressor, this should not lead to significant biases. ${ }^{33}$ Second, there is the endogeneity of regressors. Output growth is likely to be correlated with the residual. As a result, an instrumental variables approach is taken.

Equation (1) was estimated in first differences using fixed-effects two-stage least squares $(2 S L S)$ and the generalized method of moments (GMM). The $2 S L S$ estimates exhibited a number of problems, including heteroscedasticity and serial correlation. As a result, the focus will be on $G M M$ as this allows for consistent and efficient estimation in the presence of both problems when they are of an unknown form. The $G M M$ weighting matrix was chosen to account for cross-equation correlation; $2 S L S$ suggested that residuals were correlated across countries. This also accounts for different error variances in each country.

Lagged values of the endogenous variables — such as the capital stock, output, and the cost of capital-were used as instruments. ${ }^{34}$ There was evidence of partial adjustment of the capital stock, a common finding in the literature, with serial correlation emerging in some specifications. In addition, instruments at a lag order of one were rejected by tests of overidentifying restrictions. ${ }^{35}$ Lagged values of capital were inadmissible at all but long lags, which would have severely curtailed degrees of freedom. This is also indicative of partial adjustment and associated serial correlation, which renders short lags of endogenous variables invalid as instruments. This issue was first raised in the context of empirical investment equations by Bond and Cummins (2001).

Equation (1) was initially estimated in first differences including only output and the cost of capital as regressors. While consistent with the theory, the null that the instruments were

\footnotetext{
${ }^{33}$ Ellis and Price (2004) note that because output is linked to capital via the production function, this provides the equation with a degree of integral control. Another approach would be to include an estimate of capacity utilization as a control variable (e.g., Bakhshi and Thompson, 2002).

${ }^{34}$ The cost of capital was treated as endogenous, since the large real interest rate component is likely to be contemporaneously correlated with output shocks. Although, for a small open economy, the interest rate is typically regarded as exogenous, interest rates in the region have shown a lack of sensitivity to the nominal anchor, the U.S. dollar, in recent years. Other instruments used included FDI, central government investment, and credit to the private sector.

${ }^{35}$ In the Appendix tables, these tests are represented by Sargan test $p$-values. Any figure above 0.05 indicates that it was not possible to reject the null that the instruments were uncorrelated with the residual at the 5 percent level.
} 
valid was rejected for most sets of instruments chosen. When the set of regressors was expanded to include the change in the level of external public debt to GDP and the real exchange rate (both considered as endogenous and instrumented for using lagged values), the model's performance improved significantly.

\section{ESTIMATION RESULTS}

\section{A. Cost of Capital Matters for Domestic Investment}

The user cost elasticity (UCE) represents the sensitivity of capital to the cost of capital $(\mathrm{CoC})$. For private domestic capital, the UCE was negative and significant. It was, in absolute terms, toward the top end of the range of recent estimates from the literature covering advanced economies. Models using the cost of capital also outperformed those using real interest rates.

The GMM estimated UCE for the full sample is shown in the Appendix. The UCE was estimated to be around -0.12 . This compares with the most recent estimates for advanced economies in the literature, which range from -0.18 to -0.03 . The estimate was stable across a wide variety of well-specified equations. The inclusion of other control variables, including the change in real private sector credit, had a minimal effect.

The comprehensive cost of capital measure, which includes a cost of equity component, outperformed the measure based only on real interest rates in every specification. The coefficients on real interest rates for well-specified equations, when replacing the $\mathrm{CoC}$, were typically much lower with a range of between -0.05 to -0.03 . This range is similar to that observed for the real interest rate in other middle-income case studies. Moreover, when using the real interest rate in place of the $\mathrm{CoC}$, there were fewer occasions in which it was possible to reject the null that the cost term had no effect on the capital stock.

To put the UCE estimate of -0.12 into context, consider a simple example in which the cost of capital increased from 12 percent to 16 percent, a rise in the level by one-third. Many countries have experienced moves of this scale over recent years. Applying a UCE of -0.14, this would cause the optimal capital stock to decline by around 4 percent. Assume also depreciation of 10 percent and steady-state capital stock growth of 4 percent, in line with GDP. ${ }^{36}$ The change in the UCE would then imply a 29 percent decline in the investment rate. Apply the sample average private domestic investment-to-GDP ratio of 16 percent since 1990. This implies that the adjustment in the capital stock, if it occurred over one year, would be sufficient to reduce the rate of real GDP growth by over 4 percentage points.

\footnotetext{
${ }^{36}$ The economic depreciation rate is close to the empirical estimate. The relationship between private capital and output is unstable and the 4 percent figure is used only as an illustration.
} 


\section{B. Limited Effects of Output, Public Investment, and FDI}

The effect of output was in line with theory, but there was little evidence to suggest that it was significant. The coefficient on output in most estimations was around the unity implied by the model. It was also not possible to reject a restriction on this coefficient to equal one. ${ }^{37}$ In no specification was the effect of output statistically significant.

This result suggests there is little evidence to support the accelerator theory of investment. A rise in aggregate demand does not reliably bring forth additional private sector capital. There was also little evidence that public investment or FDI reliably influenced the domestic capital stock. However, multicollinearity may be depressing coefficient estimates for these two factors, particularly for public investment. As the correlation matrix in the Appendix shows, public investment is highly correlated with output and the external debt ratio.

\section{Limited Effect of the External Public Debt-to-GDP Ratio}

The coefficient on the change in the external public debt-to-GDP ratio was consistently negative and in the range of -0.11 to -0.03 , but statistically insignificant. This provides some weak evidence of a public debt overhang, with large changes in the external debt ratio depressing the growth in the domestic capital stock. Additional caution is warranted in interpreting these results, particularly given the role of natural disasters. For example, when an island is hit by a hurricane it is likely that the capital stock will rapidly decline through damage. Meanwhile, the debt ratio will increase as the authorities attempt to smooth consumption. To some extent, this is controlled for by the inclusion of output, a natural disaster dummy, the removal of extreme outliers, and the instrumenting of the debt ratio change using lagged changes.

\section{Little Evidence of Credit Rationing}

If credit rationing were prevalent, investment should be influenced by credit availability at any given interest rate, yet there was little evidence of this effect (Stiglitz and Weiss, 1981). Following Lederman and others (2003), real credit to the private sector was included in a number of specifications; under credit rationing, the coefficient on this variable should be positive and significant, while that on the cost of capital should remain negative. For specifications that passed the diagnostic tests, the coefficients were actually negative and insignificant. There was no meaningful impact on the estimates of the user cost elasticity. Even when credit replaced the cost of capital, coefficients were insignificant.

\footnotetext{
${ }^{37}$ Using standard Wald coefficient restriction tests at the 1,5 , and 10 percent significance levels.
} 


\section{ConcLusions}

This paper has three main conclusions:

- $\quad$ Real output changes do not reliably affect private domestic investment (PDI). The multiplier effects of public investment and FDI for private domestic investment are weak.

- $\quad$ PDI is sensitive to the cost of capital. Local real interest rates, the corporate tax burden, and global financial market conditions all have a major influence on the private domestic capital stock.

- $\quad$ Public policy designed to raise private domestic investment levels should focus more on creating the conditions for a lower cost of capital. Policy should focus less on relying on public investment or FDI to kick start domestic private sector growth.

- $\quad$ For the average Caribbean country, lower interest rates are likely to have a more powerful effect on the cost of capital than lower corporate tax rates.

Public policies that directly reduce, or create the conditions for a lowering of, the cost of capital should help raise PDI across CARICOM. Currently, policy in some parts of the region may be based too heavily on the presumption that only public investment and the attraction of more FDI, through costly tax concessions, can jumpstart economic growth. The evidence presented here suggests that private domestic investors are quite unresponsive to public investment and FDI. In addition, it is likely that the return to existing public capital and the linkages with the already large foreign capital stock would increase if the private domestic sector invested more in their own economies.

The effect of taxes is direct, but should not be overstated. The region has tended to base incentives on tax holidays and other measures to reduce the tax on profits. However, these are much less effective that transparently applying targeted measures such as tax credits, extended loss carry-forward periods, or refundability (Boadway and Shah, 1993; Sosa, 2006).

A simple example shows the effect of corporate taxes versus interest rates on the cost of capital for a hypothetical case based on the Caribbean sample (Table 4). The baseline is a nominal interest rate of 12 percent and a corporate tax rate of 30 percent. The table shows how the cost of capital changes for different combinations of interest rates and tax. The upper panel of Table 4 shows the results for an unchanged leverage ratio; the lower panel assumes that a firm's marginal leverage ratio decreases by 10 percentage points for each 2 percent decline in interest rates (and vice versa). This crudely attempts to capture the likely effect of lower domestic interest rates on the firm's financing decision. 
Table 4. Interest Rates, Tax Rates, and Changes in the Cost of Capital-Example 1/

Unchanged marginal debt-to-equity ratios

Interest rate (nominal, percent)

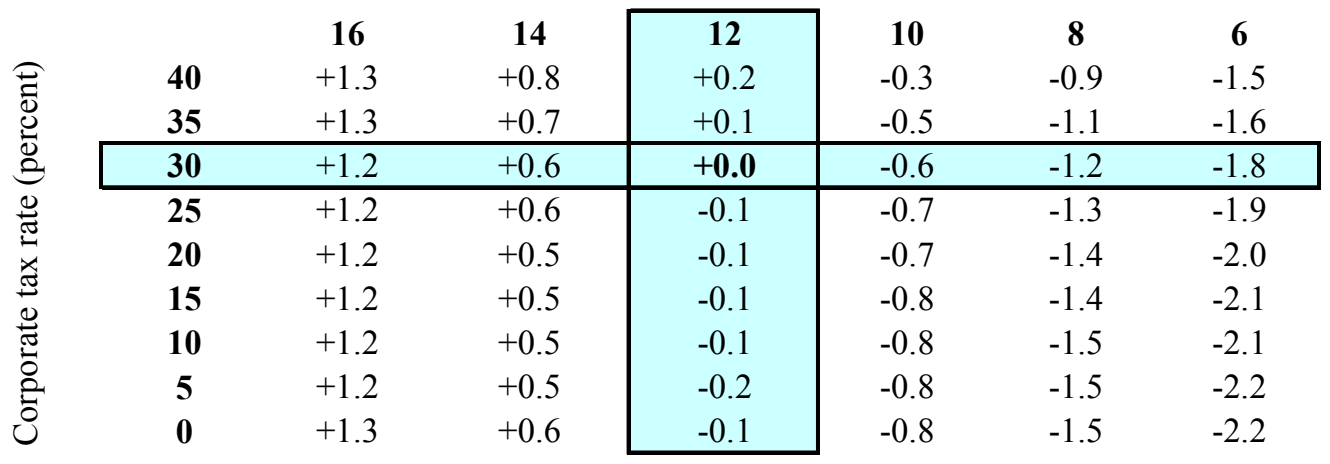

Changing marginal debt-to-equity ratios

Interest rate (nominal, percent)

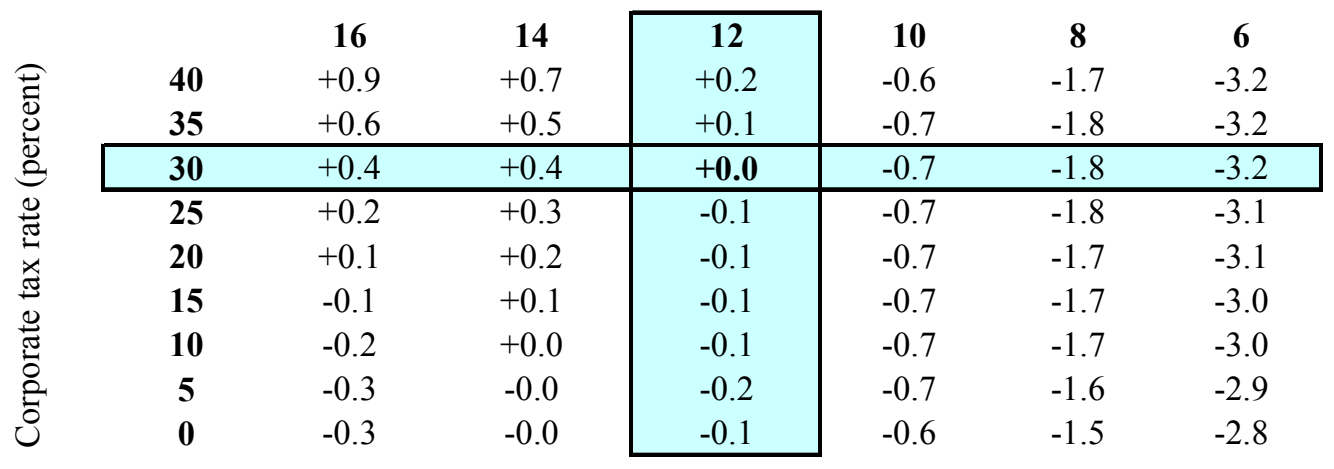

Source: Author's calculations.

1 / Inflation is set at 2 percent, the economic depreciation rate is 2 percent, the initial capital allowance is 20 percent, the proportion of initial capital allowance that reduces capital base is 100 percent, the capital allowance rate is 20 percent per annum, the weight of equity in financing is 65 percent, and the nominal cost of equity is 8 percent.

This example suggests that interest rates have a more powerful effect than corporate tax rates. This is because interest rates not only have a direct effect through borrowing costs, but they also increase the present value of future tax deductions. Also, as the lower panel shows, if firms increase leverage as a result of lower interest rates, then the deductibility of interest payments can have a powerful effect on the cost of capital for an unchanged tax rate.

Public policy is likely to be more effective in reducing the cost of capital by creating conditions that allow the pre-tax financing cost to decline. Reducing the role for the public sector might ease crowding out effects, particularly in the domestic banking system. Structural financial sector reform measures might also be considered, such as easing 
foreclosure laws. This would reduce risks for financial institutions and allow banks to provide credit at lower rates to domestic businesses.

Another key result is that regional PDI is sensitive to global market conditions. This is suggested by the cost of capital—which relies on global financial markets to estimate the equity cost component - outperforming real interest rates as a regressor. The cost of equity should be viewed as an opportunity cost of funds for the local entrepreneur. For example, the entrepreneur might invest locally in a new tourist facility or he might simply invest the funds in a global tourism sector equity fund. If the local facility is dependent upon the global tourism cycle, then both investments have comparable risk attributes. The larger the expected premium offered by the equity fund, the higher the cost of equity and the higher the expected return needs to be for the local investment.

There was little evidence of credit rationing in the sample countries. Credit rationing is a product of missing markets and asymmetric information and is often widely prevalent in developing countries (Ghosh, Mookherjee, and Ray, 2000). It is exacerbated by lenders possessing no, or little, information on potential borrowers. Banks could raise interest rates to account for these risks, but this tends to crowd out low risk borrowers. As a result, banks may simply ration credit. With little sensitivity shown by private domestic capital to changes in private sector credit, this may suggest a relative lack of demand for credit, rather than a lack of supply. 


\section{References}

Ahmed, H., and S.M. Miller, 1999, "Crowding-Out and Crowding-In Effects of the Components of Government Spending," University of Connecticut, Department of Economics Working Paper, No. 12 (Storrs, Connecticut).

Bakhshi, Hasan, Nicholas Oulton, and Jamie Thompson, 2003, "Modelling Investment when Relative Prices Are Trending: Theory and Evidence for the United Kingdom," Bank of England Working Paper, No. 189 (London: Bank of England).

Bakhshi, Hasan, and Jamie Thompson, 2002, "Explaining Trends in UK Business Investment”, Bank of England Quarterly Bulletin, Spring 2002.

Bean, C. R., 1981, “An Econometric Model of Manufacturing Investment in the U.K.," Economic Journal, Vol. 91, pp. 106-21.

Bende-Nabende, A., and J. Slater, 2003, "Private Capital Formation: Short- and Long-Run Crowding-in (out) Effects in ASEAN, 1971-99," Economics Bulletin, Vol. 3, No. 27 pp. $1-16$.

Boadway, Robin, and Anwar Shah, 1995, "Perspectives on the Role of Investment Incentives," Fiscal Incentives for Investment and Innovation, (Washington: World Bank), pp. 31-136.

Bond, Stephen, and Jason Cummins, 2001, "Noisy Share Prices and the Q Model of Investment," Institute of Fiscal Studies Working Paper, 01/22 (London).

Bouton, Lawrence, and Mariusz A. Sumlinski, 2000, "Trends in Private Investment in Developing Countries, 1970-1998," IFC Discussion Paper, Number 41 (Washington: International Finance Corporation).

Caballero, R., 1999, “Aggregate Investment," in Handbook of Macroeconomics, edited by J.B. Taylor and M. Woodford, North Holland, pp. 813-62.

Caplin, Andrew, and John Leahy, 1994, "Business as Usual, Market Crashes and Wisdom After the Fact," American Economic Review, Vol. 84, Issue 3, pp. 548-65.

Cardoso, Eliana, 1994, "Investment and Macroeconomic Adjustment: The Case of East Asia," in Striving for Growth after Adjustment: the Role of Capital Formation, L. Serven, and A. Solimano, ed. by Washington: World Bank, pp. 181-228.

Carruth Alan, Andrew Dickerson, and Andrew Henly, 2000, "Econometric Modelling of U.K. Aggregate Investment: The Role of Profits and Uncertainty," The Manchester School, Vol. 68, No. 3, pp. 276-300. 
Chai, J., and R. Goyal, 2005, "Tax Concessions and Foreign Direct Investment in the ECCU," Eastern Caribbean Currency Union: Selected Issues, IMF Country Report No. 05/305, (Washington: International Monetary Fund), pp. 73-92.

Chari, Anusha, and Peter Blair Henry, 2004, "Is the Invisible Hand Discerning or Indiscriminate? Investment and Stock Prices in the Aftermath of Capital Account Liberalizations," Stanford Graduate School of Business Research Paper No. 1839 (Stanford, California).

Chetty, Raj, 2004, "Interest Rates and Backward-Bending Investment," NBER Working Paper No. 10354 (Cambridge: National Bureau of Economic Research).

Chirinko, Robert S., 1993, "Business Fixed Investment Spending: Modelling Strategies, Empirical Results, and Policy Implications," Journal of Economic Literature, Vol. 31, No. 4, pp. 1875-911.

Cummins, Jason G., and Kevin A. Hassett, 1992, "The Effects of Taxation on Investment: New Evidence from Firm Level Panel Data," National Tax Journal, Vol. 45, pp. 243-52.

Cunningham, Rose, 2004, "Investment, Private Information, and Social Learning: A Case Study of the Semiconductor Industry," Bank of Canada Working Paper 2004-32, (Ottawa: Bank of Canada).

Damodoran, Aswath, 1996, Investment Valuation (New York: John Wiley \& Sons).

Dehn, Jan, 2000, "Private Investment in Developing Countries: the Effects of Commodity Shocks and Uncertainty," The Centre for the Study of African Economies Working Paper Series, No. 121 (Oxford).

Devereux, Michael and Fabio Schiantarelli, 1989, "Investment, Financial Factors and Cash Flow: Evidence from UK Panel Data”, NBER Working Paper 3116, (Cambridge: National Bureau of Economic Research).

Eisner, R., and M. I. Nadiri, 1968, "Investment Behavior and Neo-Classical Theory," Review of Economics and Statistics, Vol. 50, No. 3, pp. 369-82.

Ellis, Colin, and Simon Price, 2004, "U.K. Business Investment and the User Cost of Capital," The Manchester School, Supplement 2004, pp. 72-93.

Estache, Antonio, and Maria Elena Pinglo, 2004, "Are Returns to Private Infrastructure in Developing Countries Consistent with Risks since the Asian Crisis?” World Bank Policy Research Working Paper 3373, (Washington: World Bank). 
Everhart, Stephen S., and Mariusz A. Sumlinski, 2001, “Trends in Private Investment in Developing Countries 1970-2000," IFC Annual Report, Number 44, (Washington: International Finance Corporation).

Fazzari, Steven M., R. Glen Hubbard, and Bruce C. Petersen, 1988, "Financing Constraints and Corporate Investment," Brookings Papers on Economic Activity, pp. 141-95.

Gendron, Pierre-Pascal, Gordon Anderson, and Jack M. Mintz, 2003, "Corporation Tax Asymmetries and Firm-Level Investment in Canada,” ITP Paper 0303, (Toronto: University of Toronto).

Ghosh, Parikshit, Dilip Mookherjee, and Debraj Ray, 2000, "Credit Rationing in Developing Countries" in A Reader in Development Economics (London: Blackwell).

Goolsbee, Austin, 2000, "The Importance of Measurement Error in the Cost of Capital," National Tax Journal, Vol. 53, pp. 215-28.

Hall, Robert E., and Dale W. Jorgenson, 1967, “Tax Policy and Investment Behavior," American Economic Review, Vol. 57, pp. 391-414.

Hayashi, Fumio, 1982, "Tobin's Marginal q and Average q: A Neoclassical Interpretation," Econometrica, Vol. 50, pp. 213-24.

Hicks, John R., 1981, Wealth and Welfare: Vol. I. of Collected Essays in Economic Theory, (London: Harvard University Press).

Hoshi, Takeo; Kashyap, Anil, and Scharfstein, David, 1991, "Corporate Structure, Liquidity and Investment: Evidence from Japanese Industrial Groups", Quarterly Journal of Economics, Vol. 106, Issue 1, pp. 33-60.

International Monetary Fund, 1993, System of National Accounts (Washington: International Monetary Fund).

Jorgenson, Dale W., 1963, "Capital Theory and Investment Behavior," AEA Proceedings, Vol. 53, pp. 247-59.

Khan, Mohsin S. and Manmohan S. Kumar, 1997, "Public and Private Investment and The Growth Process in Developing Countries", Oxford Bulletin of Economics and Statistics, Vol. 59, No. 1, pp. 69-88.

KPMG Worldwide Corporate Tax Rates Surveys, 1980 to 2004, (New York).

Larrain, Felipe, and Rodrigo Vergara, 1993, "Investment and Macroeconomic Adjustment: The Case of East Asia" in Striving for Growth after Adjustment: The Role of Capital Formation, ed. by L. Serven, and A. Solimano, (Washington: World Bank) pp. 229-74. 
Lederman, Daniel, Ana Maria Menendez, Guillermo Perry, and Joseph Stiglitz, 2003, "Mexican Investment After the Tequila Crisis: Basic Economics, "Confidence" Effects, or Market Imperfections?" Journal of International Money and Finance, Vol. 22, pp. 131-51.

Mataya, C., and M. Veeman, 1996, "The Behaviour of Private and Public Investment in Malawi," Canadian Journal of Economics, Vol. 29(s1), pp. 438-42.

McKenzie, Kenneth J., and Aileen J. Thompson, 1997, "Taxes, the Cost of Capital, and Investment: A Comparison of Canada and the United States," Technical Committee on Business Taxation, Working Paper 97-3, (Ottawa: Canada Department of Finance).

McMahon, Michael, Gabriel Sterne, and Jamie Thompson, 2005, "The Role of ICT in the Global Investment Cycle,” Bank of England Working Paper, (London: Bank of England).

Nehru, Vikram, and Ashok Dhareshwar, 1993, "A New Database on Physical Capital Stock: Sources, Methodology and Results," Revista de Analisis Economico, Vol. 8, No. 1, pp. 37-59.

OECD Manual, 2001, Measuring Capital, (Paris: Organization for Economic Cooperation and Development).

Oshikoya, Temitope W., 1994, "Macroeconomic Determinants of Domestic Private Investment in Africa: An Empirical Analysis," Economic Development and Cultural Change, Vol. 42, pp. 573-96.

Pindyck, Robert S., 1991, "Irreversibility, Uncertainty and Investment," Journal of Economic Literature, Vol. 29, pp. 1110-148.

Pedroni, Peter, 1999, "Critical Values for Cointegration Tests in Heterogeneous Panels with Multiple Regressors," Oxford Bulletin of Economics and Statistics, Vol. 61, Special Issue, pp. 653-70.

Pedroni, Peter, 2000, "Fully Modified OLS for Heterogeneous Cointegrated Panels," Nonstationary Panels, Panel Cointegration, and Dynamic Panels, Vol. 15, pp. 93-130.

Pesaran, M. Hashem, Yongcheol Shin, and Ron P. Smith, 1999, "Pooled Mean Group Estimation of Dynamic Heterogeneous Panels," Journal of the American Statistical Association, Vol. 94, pp. 621-34.

Rama, Martin, 1994, "Empirical Investment Equations in Developing Countries" in Striving for Growth after Adjustment: The Role of Capital Formation, ed. by L. Serven, and A. Solimano (Washington: World Bank), pp. 229-74. 
Rasmussen, Tobias N., 2004, "Macroeconomic Implications of Natural Disasters in the Caribbean,” IMF Working Paper No. 04/224 (Washington: International Monetary Fund).

Schiantarelli, F., and M. Georgoutsos, 1987, "Monopolistic Competition and the Q Theory of Investment," IFS Working Paper No. 87/13 (London: Institute of Fiscal Studies).

Sosa, S., 2006, “Tax Incentives and Investment in the Eastern Caribbean,” IMF Working Paper No. 06/23, (Washington: International Monetary Fund).

Stiglitz, J. E., and A. Weiss, 1981, "Credit Rationing in Markets with Imperfect Information," American Economic Review, Vol. 71, pp. 393-410.

Tevlin, Stacey, and Karl Whelan, 2003, "Explaining the Investment Boom of the 1990s", Journal of Money, Credit and Banking, Vol. 35, No. 1, pp. 1-22.

Vergara, Rodrigo, 2004, "Taxation and Private Investment: Evidence for Chile," Universidad Catolica de Chile (Mimeo; Santiago). 


\section{Data Sources and Estimates}

\section{A. Capital Stock Data-Issues and Measurement}

Although the focus is on private domestic investment, data limitations forced estimates of the capital stock to include the non-central government public sector. ${ }^{38}$ In many countries, there were gaps in the provision of consolidated public sector data in published IMF staff reports, the principal source of fiscal data in this study, particular after the late 1990s. Although this may cause some problems when assessing the determinants of investment, in the sense that public agencies may not be subject to the same market forces as private investors, the magnitude of the problem may be modest. For example, for the ten years through 2003, noncentral government public capital expenditure, where the data was available, was estimated to be around 2 percent of GDP, compared to 9 percent for the central government and 12 percent for FDI.

The initial capital stock was estimated using techniques described in Nehru and Dhareshwar (1993). This is based on a rearrangement of the basic real capital stock accumulation equation:

$$
K_{t+1}=I_{t}+(1-\delta) K_{t}
$$

At the steady state, the capital-output ratio should be stable, so that capital is growing at the real rate of output $g$. This implies that the capital stock, at some arbitrarily chosen time 0 , may be written as:

$$
K_{0}=\frac{I_{0}}{E_{0}\{g+\delta\}}
$$

The real output growth rate $g$ and the rate of depreciation $\delta$ were based on five-year averages, with the estimated year at the center of the average. Clearly this estimate of the capital stock is sensitive to the level of investment in any one particular year. To minimize measurement error based on a single observation of $I$, Nehru and Dhareshwar (1993) propose that the initial value should be interpolated using a linear time trend, that is: $\log \left(I_{t}\right)=a+b t+e_{t}$, which implies $E\left\{K_{0}\right\}=\exp (a+b t) / E\{g+\delta\}$.

The capital stock is then estimated using the perpetual inventory method, where:

$$
K_{t+1}=\frac{I_{t}^{N}}{p_{t}^{K}}+(1-\theta-\delta) K_{t} \text {. }
$$

In almost all cases, only nominal investment $I^{N}$ is provided by the authorities. The OECD STAN database was used for a number of variables required to compute the real capital

\footnotetext{
${ }^{38}$ For most Caribbean countries, this covers mainly publicly owned companies such as utilities, rather than regional public administration.
} 
stock. ${ }^{39}$ The implicit assumption made is that each sector in the Caribbean exhibited the same pattern of capital formation as their OECD sector peers. At the aggregate level, construction does appear to be a larger component of investment in the Caribbean, but the differences are not significant. ${ }^{40}$ To deflate these series, a value added sector-weighted average of the OECD global sector investment goods deflator was used. This relies on two implicit assumptions. The first is that the proportion of new investment in the economy by any sector is related to its value added. The second is that domestic firms pay the world price for capital goods; given that most countries allow the purchase of capital goods on a duty-free basis and that most capital goods are imported, this appears a reasonable assumption.

The depreciation rate $\delta$ was also based on a value added sector-weighted average of the OECD global sector capital depreciation rate. An additional term was the effect of natural disasters on the level of capital stock $\theta$. These estimates are subject to a high degree of uncertainty and were based on the EM-DAT natural disasters database. Where data did not exist, data from the Caribbean Disaster Emergency Response Agency and local news media sources were used, where available. Outliers removed were St. Kitts 1996 (Hurricane Luis), St. Lucia 1988 (Hurricane Gilbert) and 1996 (significant drop in FDI not reflected on overall investment), and Jamaica 1992 (due to intense capital market volatility). Depreciations rates in the region, even before natural disasters, are higher than in the OECD. However, there is no data which would allow an estimate of this differential. The estimations used differenced variables, so unless this differential is changing over time, it is unlikely to affect the results.

\section{B. Real User Weighted-Average Cost of Capital}

To derive the weighted-average cost of capital, it is appropriate to start from the firm's dividend stream is equal to the after-tax value of output $D_{t}=(1-u) p_{t} F\left(K_{t}^{P}, K_{t}^{G}, K_{t}^{F}, N_{t}\right)-w_{t} N_{t}-(1-\eta) p_{t}^{K} I_{t}+u \alpha A_{t}+\left(B_{t+1}-B_{t}\right)-i_{t}(1-u) B_{t}$

where

$u \equiv$ corporate tax rate

$p \equiv$ output price

$p^{K} \equiv$ capital goods price

$\eta \equiv$ investment tax credit or the product of $u$ and the immediate capital allowance rate ${ }^{41}$

${ }^{39}$ The definition of capital used by the STAN is consistent with the UN Handbook of National Accounting, or SNA (IMF, 1993). This concept includes only produced capital goods (machinery, buildings, roads, artistic originals etc.) and improvements to non-produced assets. Gross capital formation measures the additions to the capital stock of buildings, equipment and inventories, that is, the additions to the capacity to produce more goods and income in the future.

${ }^{40}$ For the OECD, construction accounts around 55 percent of gross fixed capital formation using data from 1980 to 2004. For the sample of Caribbean countries, the average is around 62 percent.

${ }^{41}$ Note that the tax credit, in the form of an accelerated allowance, is given by $\eta=u z$ where $z$ is defined as the immediate capital allowance rate. 
$\delta \equiv$ economic depreciation rate

$\alpha \equiv$ tax depreciation/ capital allowance rate

$A \equiv$ undepreciated capital base for tax purposes

$B \equiv$ outstanding firm debt in nominal terms

$i \equiv$ nominal interest rate

In general, using this equation as the foundation for the firm's value maximization problem will not produce an interior solution, since it is monotonic in $B$, or nominal debt. A common feature of this literature is to avoid this problem by setting the debt/equity ratio to a constant $b=B / S$ (see Boadway and Shah, 1993). Rewriting the dividend stream by using $X$ to denote actual cashflow to the firm, plus transactions with nonshareholders, as:

$D_{t}=X_{t}+b \Delta S_{t+1}-i_{t}(1-u) b S_{t}$.

Substitute this dividend stream into the capital markets equilibrium condition which states that the return on equity $\gamma$ is equal to post-tax dividends received, plus the post-tax capital gain:

$\gamma \cdot S_{t}=(1-\theta) D_{t}+(1-c) \Delta S_{t+1}$.

This obtains:

$$
S_{t}\left[1+\frac{\gamma}{(1-c)}+b \frac{(1-\theta)}{(1-c)}\left(1+i_{t}(1-u)\right)\right]=\frac{(1-\theta)}{(1-c)} X_{t}+\left(1+b \frac{(1-\theta)}{(1-c)}\right) S_{t+1}
$$

Repeated iteration obtains the usual relationship showing the current value of equity as the presented discounted sum of future cashflows to equity holders. The discount rate used is derived from the parameters introduced above and is the weighted average cost of capital (WACC), denoted by :

$$
\frac{1}{\left(1+\rho_{t}\right)}=\frac{\left(1+b \frac{(1-\theta)}{(1-c)}\right)}{\left(1+\frac{\gamma}{(1-c)}+b \frac{(1-\theta)}{(1-c)}\left(1+i_{t}(1-u)\right)\right)}
$$

In this paper, the cost of capital will exclude the effects of capital gains and income taxes, a common practice in the literature. This obtains:

$\rho_{t}=\frac{\gamma_{t}+b i_{t}(1-u)}{(1+b)}=w_{e} \gamma_{t}+w_{d} i_{t}(1-u)$.

This is then the nominal cost of finance for the firm. It is a weighted average of the cost of equity and the cost of debt. 
The shares of debt and equity should correspond to the market value proportion of the funding type in the overall funding mix (Damodoran, 1996). In general, this should reflect the funding mix for marginal investment, but in common with the literature, estimates of the average funding mix are used. Specifically, the shares are estimated as:

$w_{d}=\frac{1}{T} \sum_{s=t}^{T} \frac{B_{s}}{p_{s}^{K} \widetilde{K}_{s}} \quad$ and $\quad w_{e}=\frac{1}{T} \sum_{s=t}^{\infty} \frac{p_{s}^{K} \widetilde{K}_{s}-B_{s}}{p_{s}^{K} \widetilde{K}_{s}}$

where

$B \equiv$ nominal book value of outstanding debt to the domestic commercial sector

$\widetilde{K} \equiv$ estimated domestic private sector capital stock

$p^{K} \equiv$ price of one unit of the domestic private sector capital stock.

The nominal cost of debt $i$ is taken to be the lending rate on commercial loans as published in International Financial Statistics. This is adjusted by the statutory rate of corporate taxation $u$ to account for the deductibility of interest payments. In general, the commercial rate is based on the prime rate, a benchmark off which commercial loans are priced. Use of the benchmark therefore implies that the distribution of loan pricing around this benchmark is symmetric; a weighted-average effective commercial lending rate is not available for the region. This suggests that the interest rate measure may be subject to measurement error, particularly when the distribution of actual rates is asymmetric. The real cost of debt is then calculated by applying tax deductibility at the statutory corporate tax rate and deflating using the GDP deflator. The deflator was used as it is an approximate measure of the change in prices of domestically produced goods. The one exception was Jamaica, which has a record of high deflator volatility; in this case the nominal interest rates was deflated using the tenyear average change in the deflator to reflect that expectations are likely to be more stable than actual inflation.

The real cost of equity is given by the capital asset pricing model. This is the U.S. dollar benchmark long-term "risk-free rate," plus the local beta adjusted global equity risk premium, adjusted for U.S. dollar inflation. The U.S. inflation rate is used since the benchmark risk-free rate is U.S. dollar denominated. In effect, the cost of equity represents an opportunity cost:

$\gamma_{j t}=i_{t}^{U S}+\sum_{l=1}^{M} w_{j l} \beta_{l}\left[E\left(r_{m t}\right)-i_{t}^{U S}\right]-\pi_{t}^{U S}$

where

$i^{U S} \equiv$ U.S. Treasury 10 -year note yield to maturity

$w_{j l} \equiv$ weight of industry $l$ in the local economy by value added

$\beta_{j l} \equiv$ beta of global industry $l$ to the global equity market

$E\left(r_{m}\right) \equiv$ expected return on the global equity market

$\pi^{U S} \equiv$ U.S. consumer price index inflation. 
The capital asset pricing model (CAPM) beta is a measure of undiversifiable risk. Volatility of returns may also be used as a risk measure. However, as CARICOM countries are characterized by relatively open capital accounts, it is assumed that much of this overall volatility may be diversified away by investors. It was estimated by an OLS regression of the returns of a weighted portfolio of assets designed to replicate private investment in each country on the returns of the global equity market. A CAPM beta greater than one suggests that the asset (or investment) exposes the investor to more systematic risk and, as a result, the equilibrium return must be higher to compensate. The weights in each country-specific portfolio are chosen to reflect two aspects of the equity investment decision: (i) the sector exposure of the average country investment, derived from the structure of GDP; (ii) the risk exposure of emerging markets more generally. The first aspect may be modeled on the basis of the major export sectors of the economy. For example, the risk profile for an investment in the Caribbean tourism sector is more likely determined by the risk profile of the global tourism market, rather than the local economy. This risk aspect was accounted for using Datastream Global Equity Market Sector total return indices denominated in U.S. dollars, available from 1978. The second aspect used the MSCI Emerging Markets Free Total Return Index denominated in U.S. dollars, available from 1992. The weights of each relevant global equity sector are determined by the value-added contribution of that export sector to GDP each year; in the case of agriculture and manufacturing, all product is assumed to be exportable and subject to global market conditions. The residual is then accounted for by the emerging markets beta. For the pre-1992 period for which the emerging market beta is unavailable, the beta of the countries nominal GDP to the World GDP growth rate is used, controlling for identified natural disaster shocks. ${ }^{42}$

The country-specific CAPM betas were then used as multipliers for the expected return on the global equity market. This was derived from a one-stage dividend discount model. Assuming constant dividend growth, the expected return on the market may be expressed as the current dividend yield, plus the long-term expected growth rate in dividends:

$E\left(r_{m t}\right)=\frac{\delta_{t}}{p_{t}}+E_{t}(\hat{\delta})$

The expected growth rate in dividends was estimated by assuming a 3 percent trend growth rate for real GDP and adding to that the trailing 15-year moving average for the GDP deflator for the OECD. The problem with this extraction of the equity risk premium is that the expected long-term growth rate must be imposed and, in this case, is constant. However, fluctuations in the dividend yield and inflation provide a degree of time variation that is missing from other studies that have relied on global or U.S. equity risk premia (e.g., Estache and Pinglo, 2004).

\footnotetext{
${ }^{42}$ A simple regression is used to derive the beta, with a dummy variable used for natural disaster shocks. The major drawback of this measure is that it is backward looking and may not have particular relevance for an investor with a long horizon.
} 


\section{Tax Factors}

Tax data was sourced from the international tax surveys conducted by global accounting firms, and from the International Bureau of Fiscal Documentation. In all cases, the published statutory rates of taxation were used in the calculation of effective marginal rates.

The principal dichotomy of tax treatment of investment is between buildings and all other types of capital good. Typically, investment in machinery and equipment enjoys a much lower tax burden than buildings and, in some cases, is often subsidized by the tax system. Subsidization is often in the form of accelerated capital allowances and tax credits that do not reduce the cost base used for future allowance treatment. To reflect this dichotomy, the tax factor for each country is a weighted-average for construction and nonconstruction gross fixed capital formation. There are also differences in the treatment of different varieties of machinery and equipment and, in these cases, a simple average was used. Tariff rates were not included in the calculation of the effective marginal rate of taxation, since in all of the countries in the sample, capital goods were exempt from duty. In many countries, tariffs are applied to construction materials but, in the absence of large changes in these tariffs, omitting them should have a minimal impact.

Another major consideration is the method of allowable depreciation. The two most common forms of depreciation schedule are the declining-balance and straight line methods. The declining-balance method involves depreciating the book value of capital at a certain percentage each year; as a result, for any given vintage of capital stock, the depreciation is exponential. This was the method applied to all countries except Barbados, which used the straight-line method. This method depreciates the book value by the same nominal amount each year and is linear. 


\section{Summary Statistics}

Appendix Table 1. Summary Statistics for Log-Differenced Variables

\begin{tabular}{lccccccc}
\hline & Mean & Median & Maximum & Minimum & Std. Dev. & Skewness & Kurtosis \\
\hline Capital & 0.03 & 0.03 & 0.19 & -0.25 & 0.06 & -0.81 & 6.79 \\
Output & 0.03 & 0.03 & 0.14 & -0.05 & 0.03 & 0.36 & 3.81 \\
Cost of capital & 0.01 & -0.01 & 1.02 & -0.35 & 0.18 & 1.82 & 10.63 \\
Real interest rate & 0.03 & 0.01 & 1.78 & -1.30 & 0.34 & 1.19 & 11.05 \\
External debt-GDP & 0.01 & 0.00 & 0.90 & -0.31 & 0.15 & 1.98 & 13.27 \\
Real exchange rate & -0.01 & 0.00 & 0.17 & -0.15 & 0.05 & 0.09 & 4.15 \\
FDI (real) & 0.14 & 0.11 & 2.09 & -1.59 & 0.52 & 0.35 & 5.17 \\
Public investment (real) & 0.03 & 0.04 & 2.15 & -2.08 & 0.57 & 0.35 & 6.97 \\
Credit to private sector (real) & 0.05 & 0.05 & 0.29 & -0.95 & 0.13 & -3.97 & 30.22 \\
\hline
\end{tabular}

Source: Author's calculations.

\section{Appendix Table 2. Correlation Matrix Across Equation Variables}

\begin{tabular}{|c|c|c|c|c|c|c|c|c|c|}
\hline \multirow{2}{*}{\multicolumn{10}{|c|}{ Log levels }} \\
\hline Capital & 100 & & & & & & & & \\
\hline Output & 0.98 & 1.00 & & & & & & & \\
\hline Cost of capital & 0.55 & 0.54 & 1.00 & & & & & & \\
\hline Real interest rate & 0.14 & 0.17 & 0.26 & 1.00 & & & & & \\
\hline External debt-GDP & 0.15 & 0.08 & 0.27 & 0.11 & 1.00 & & & & \\
\hline Real exchange rate & -0.17 & -0.15 & 0.30 & 0.05 & -0.22 & 1.00 & & & \\
\hline FDI (real) & 0.70 & 0.75 & 0.44 & 0.27 & 0.21 & -0.19 & 1.00 & & \\
\hline Public investment (real) & 0.86 & 0.90 & 0.63 & 0.23 & 0.10 & -0.01 & 0.71 & 1.00 & \\
\hline Credit to private sector (real) & 0.96 & 0.98 & 0.48 & 0.25 & 0.12 & -0.14 & 0.76 & 0.89 & 1.00 \\
\hline \multicolumn{10}{|l|}{ Log first differences } \\
\hline Capital & 1.00 & & & & & & & & \\
\hline Output & 0.12 & 1.00 & & & & & & & \\
\hline Cost of capital & -0.10 & -0.06 & 1.00 & & & & & & \\
\hline Real interest rate & -0.09 & 0.14 & 0.53 & 1.00 & & & & & \\
\hline External debt-GDP & 0.04 & -0.07 & 0.08 & 0.03 & 1.00 & & & & \\
\hline Real exchange rate & -0.05 & -0.17 & 0.01 & 0.06 & -0.39 & 1.00 & & & \\
\hline FDI (real) & -0.30 & 0.01 & -0.02 & -0.15 & 0.03 & -0.19 & 1.00 & & \\
\hline Public investment (real) & -0.16 & 0.20 & 0.05 & -0.01 & 0.10 & 0.06 & 0.17 & 1.00 & \\
\hline Credit to private sector (real) & 0.15 & 0.24 & -0.30 & -0.03 & -0.11 & 0.09 & -0.09 & 0.08 & 1.00 \\
\hline
\end{tabular}

Source: Author's calculations 
E. Unit Root Tests

Appendix Table 3. Panel Unit Root Tests

\begin{tabular}{|c|c|c|c|c|c|c|c|c|}
\hline & \multicolumn{4}{|c|}{ Log levels } & \multicolumn{4}{|c|}{ Log first differences } \\
\hline & $\begin{array}{c}\text { Test } \\
\text { Statistic }\end{array}$ & $\begin{array}{c}\mathrm{p} \\
\text { value }\end{array}$ & $\begin{array}{c}\text { No. of } \\
\text { countries }\end{array}$ & $\begin{array}{c}\text { No. of } \\
\text { obs. }\end{array}$ & $\begin{array}{c}\text { Test } \\
\text { Statistic }\end{array}$ & $\begin{array}{c}\mathrm{p} \\
\text { value }\end{array}$ & $\begin{array}{c}\text { No. of } \\
\text { countries }\end{array}$ & $\begin{array}{c}\text { No. of } \\
\text { obs. }\end{array}$ \\
\hline \multicolumn{9}{|l|}{ Capital } \\
\hline Im, Pesaran and Shin W-stat & 3.70 & 0.9999 & 5 & 100 & -1.57 & 0.0586 & 7 & 109 \\
\hline ADF - Fisher Chi-square & 6.37 & 0.7837 & 5 & 100 & 24.30 & 0.0422 & 7 & 109 \\
\hline PP - Fisher Chi-square & 6.13 & 0.9632 & 7 & 129 & 30.44 & 0.0066 & 7 & 116 \\
\hline \multicolumn{9}{|l|}{ Output } \\
\hline Im, Pesaran and Shin W-stat & -0.90 & 0.1836 & 7 & 155 & -4.76 & 0.0000 & 7 & 150 \\
\hline ADF - Fisher Chi-square & 18.14 & 0.2004 & 7 & 155 & 53.52 & 0.0000 & 7 & 150 \\
\hline PP - Fisher Chi-square & 18.88 & 0.1694 & 7 & 160 & 55.68 & 0.0000 & 7 & 153 \\
\hline \multicolumn{9}{|l|}{ Cost of capital } \\
\hline Im, Pesaran and Shin W-stat & -7.94 & 0.0000 & 7 & 127 & -11.76 & 0.0000 & 7 & 119 \\
\hline ADF - Fisher Chi-square & 88.04 & 0.0000 & 7 & 127 & 160.42 & 0.0000 & 7 & 119 \\
\hline PP - Fisher Chi-square & 78.64 & 0.0000 & 7 & 134 & 771.65 & 0.0000 & 7 & 127 \\
\hline \multicolumn{9}{|l|}{ Real interest rates } \\
\hline Im, Pesaran and Shin W-stat & -5.26 & 0.0000 & 7 & 129 & -11.93 & 0.0000 & 7 & 127 \\
\hline ADF - Fisher Chi-square & 59.65 & 0.0000 & 7 & 129 & 125.60 & 0.0000 & 7 & 127 \\
\hline PP - Fisher Chi-square & 62.80 & 0.0000 & 7 & 139 & 461.47 & 0.0000 & 7 & 132 \\
\hline \multicolumn{9}{|l|}{ External debt-GDP } \\
\hline Im, Pesaran and Shin W-stat & -1.75 & 0.0398 & 7 & 147 & -3.88 & 0.0001 & 7 & 143 \\
\hline ADF - Fisher Chi-square & 22.43 & 0.0702 & 7 & 147 & 41.00 & 0.0002 & 7 & 143 \\
\hline PP - Fisher Chi-square & 13.83 & 0.4627 & 7 & 153 & 46.30 & 0.0000 & 7 & 146 \\
\hline \multicolumn{9}{|l|}{ Real exchange rates } \\
\hline Im, Pesaran and Shin W-stat & 0.83 & 0.7975 & 7 & 163 & -6.42 & 0.0000 & 7 & 158 \\
\hline ADF - Fisher Chi-square & 14.13 & 0.4400 & 7 & 163 & 63.96 & 0.0000 & 7 & 158 \\
\hline PP - Fisher Chi-square & 12.60 & 0.5582 & 7 & 165 & 63.00 & 0.0000 & 7 & 158 \\
\hline \multicolumn{9}{|l|}{ FDI } \\
\hline Im, Pesaran and Shin W-stat & 1.03 & 0.8480 & 7 & 137 & -10.88 & 0.0000 & 7 & 130 \\
\hline ADF - Fisher Chi-square & 10.64 & 0.7138 & 7 & 137 & 118.67 & 0.0000 & 7 & 130 \\
\hline PP - Fisher Chi-square & 43.95 & 0.0001 & 7 & 139 & 197.93 & 0.0000 & 7 & 131 \\
\hline \multicolumn{9}{|l|}{ Public investment } \\
\hline Im, Pesaran and Shin W-stat & -2.75 & 0.0030 & 7 & 142 & -7.34 & 0.0000 & 7 & 132 \\
\hline ADF - Fisher Chi-square & 32.68 & 0.0032 & 7 & 142 & 76.93 & 0.0000 & 7 & 132 \\
\hline PP - Fisher Chi-square & 25.63 & 0.0289 & 7 & 145 & 265.92 & 0.0000 & 7 & 138 \\
\hline \multicolumn{9}{|l|}{ Credit to the private sector } \\
\hline Im, Pesaran and Shin W-stat & 1.12 & 0.8678 & 7 & 167 & -7.23 & 0.0000 & 7 & 160 \\
\hline ADF - Fisher Chi-square & 11.02 & 0.6842 & 7 & 167 & 73.15 & 0.0000 & 7 & 160 \\
\hline PP - Fisher Chi-square & 10.94 & 0.6910 & 7 & 167 & 77.13 & 0.0000 & 7 & 160 \\
\hline
\end{tabular}

Source: Author's calculations 


\section{F. Panel Cointegration Tests}

Four specifications were tested using the Pedroni panel cointegration test procedures:

- $\quad$ Specification 1 tested equation (1) derived from the firms value maximization problem for all seven countries in the sample.

- $\quad$ Specification 2 tested equation (2) for the sample excluding Trinidad and Tobago.

- $\quad$ Specification 3 included the real exchange rate, the level of external public debt as a percent of GDP, and real credit to the private sector.

- $\quad$ This set of variables was also used in specification 4, but the sample again excluded Trinidad and Tobago.

Appendix Table 4. Panel Cointegration Tests 1/

\begin{tabular}{lcccc}
\hline & \multicolumn{4}{c}{ Specification } \\
& $\mathbf{1}$ & $\mathbf{2}$ & $\mathbf{3}$ & $\mathbf{4}$ \\
\hline & & & & \\
Panel v-stat & 0.96 & 0.44 & 1.65 & 1.14 \\
Panel rho-stat & 0.78 & 0.63 & 2.54 & 3.26 \\
Panel PP-stat & -0.70 & -1.44 & -2.48 & 0.96 \\
Panel ADF-stat & -2.19 & -2.19 & 0.67 & 1.21 \\
& & & & \\
Group rho-stat & 1.83 & 1.55 & 3.80 & 4.20 \\
Group PP-stat & -0.29 & -1.30 & -10.63 & -5.74 \\
Group ADF-stat & 0.20 & 0.14 & 3.16 & 2.07 \\
& & & & 6 \\
Countries & 7 & 6 & 7 & ex-Trinidad \\
Sample & full & ex-Trinidad & full & 7 \\
Regressors & 2 & 2 & 7 & \\
\hline
\end{tabular}

Source: Author's calculations.

$1 /$ All reported values are distributed as $\mathrm{N}(0,1)$ under the null of no cointegration. All tests are taken from Pedroni (1999). Panel v-stat refers to the pooled variance ratio statistic, a nonparametric test analogous to the Philips-Ouliaris variance statistic. Panel rho-stat refers to the pooled semi-parametric test analogous to the Phillips-Perron rho-statistic. Panel pp-stat refers to the pooled semi-parametric test analogous to the Phillips-Perron t-statistic. Panel adf-stat refers to the pooled parametric test analogous to the augmented Dickey-Fuller t-statistic. Group statistics are based on the same tests, but these tests are "between dimension" rather than "within dimension." 


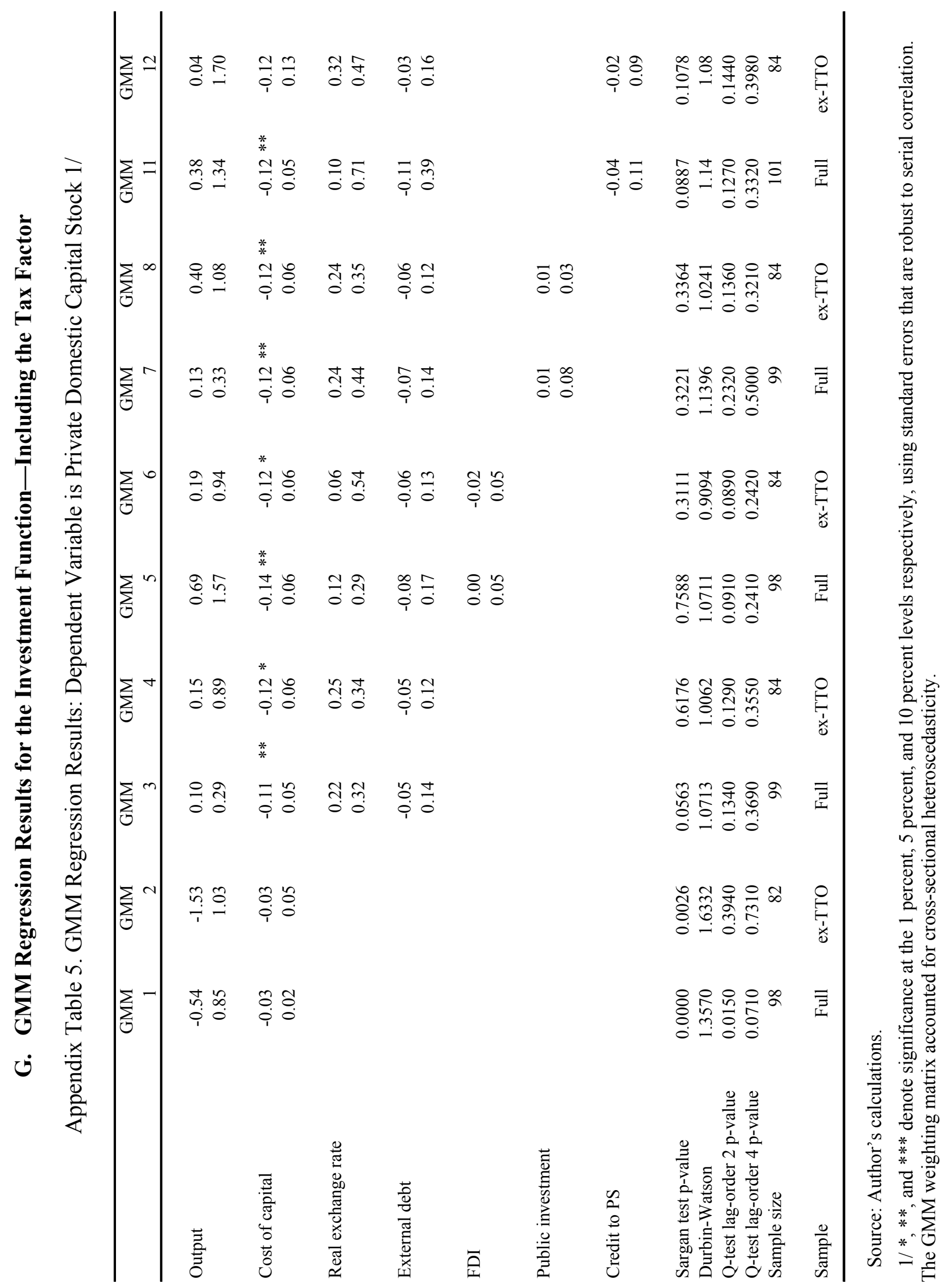




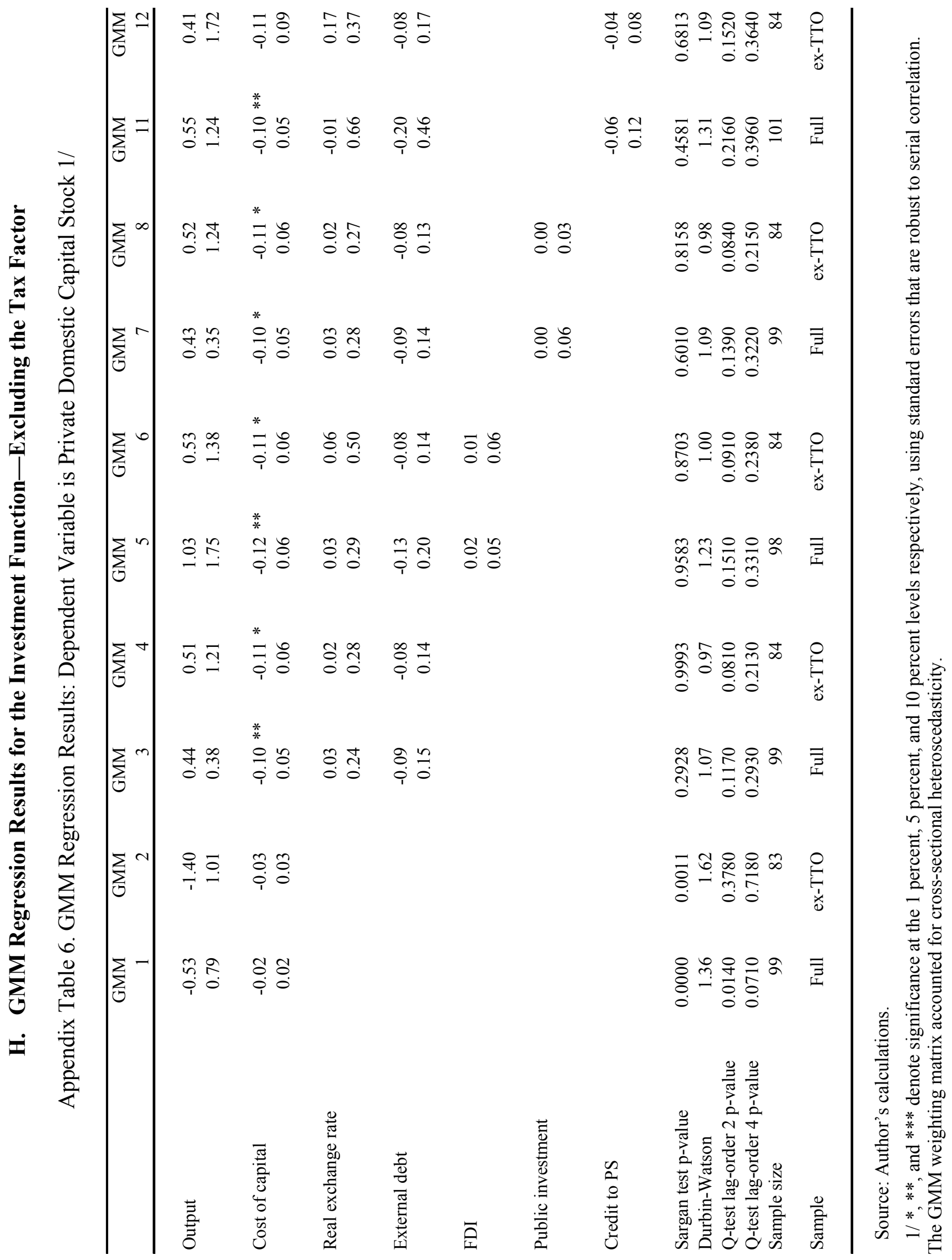




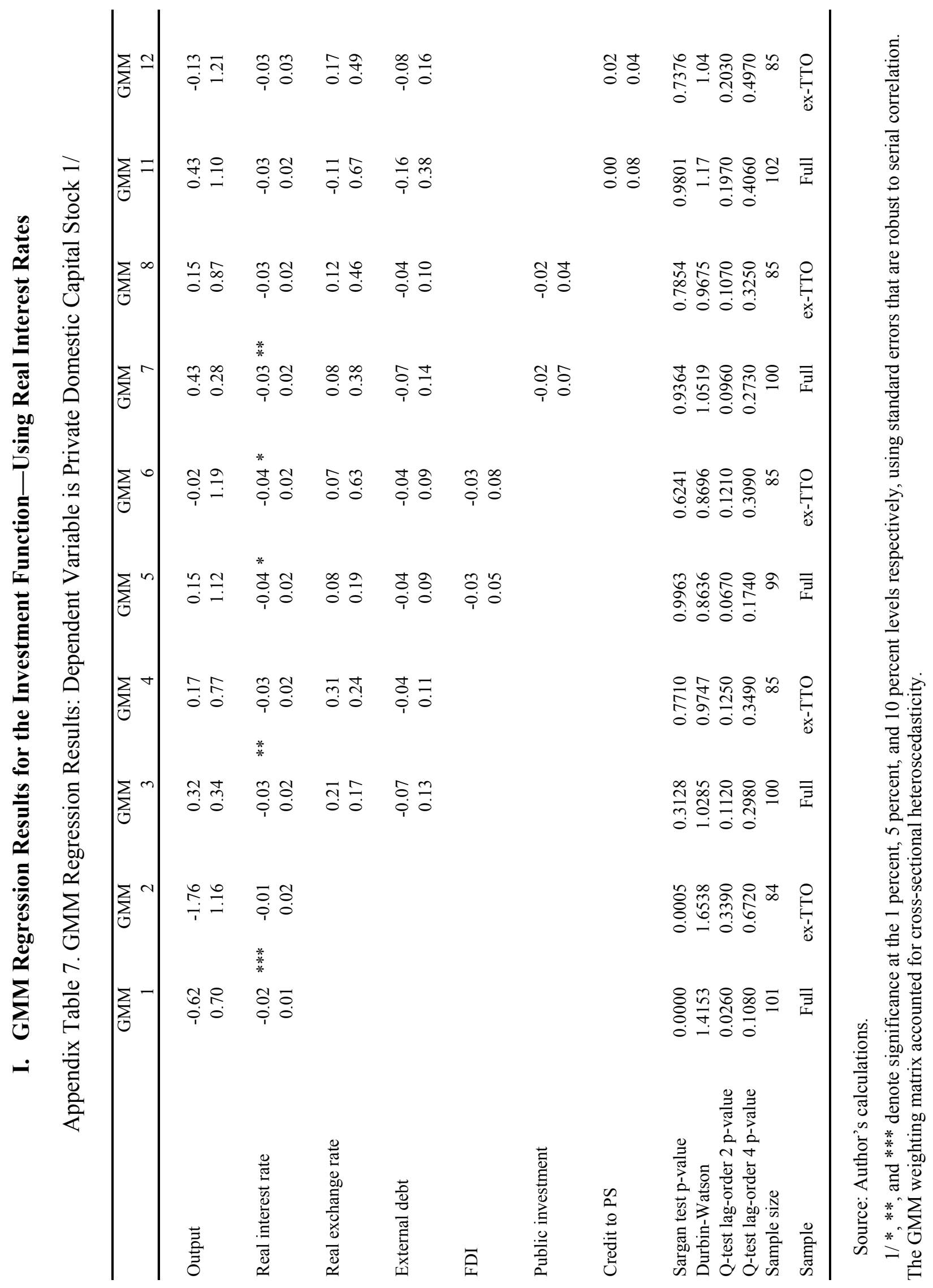

